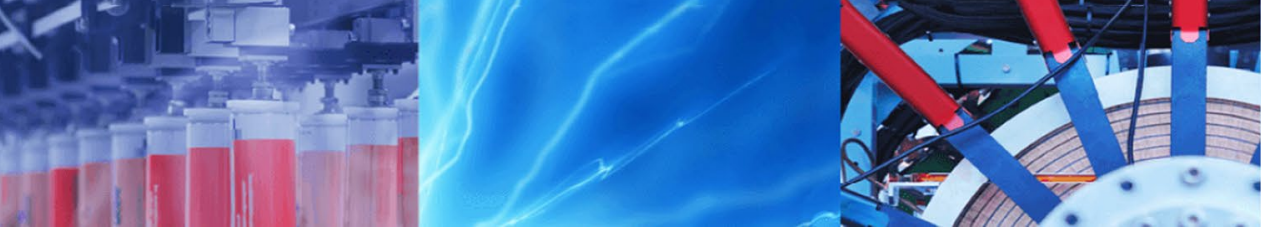

Research Article

\title{
Thermodynamic simulation in evaluating the role of minor oxides and mineralizers in Portland cement clinker phase formation
}

\author{
A. Tazuddin ${ }^{1}$ (D) Hemantkumar Aiyer ${ }^{1} \cdot$ Amit Chatterjee $^{1}$
}

Received: 12 February 2020 / Accepted: 17 September 2020 / Published online: 26 September 2020

(c) Springer Nature Switzerland AG 2020

\begin{abstract}
The present investigation reveals the importance of the minor oxides and mineralizers on the formation of the critically important cement phases (i.e., $C_{3} S, C_{2} S, C_{3} A$ and $C_{4} A F$ ) which demonstrate their fundamental role in the development of critical properties of cement. Thermodynamic investigation using CALculation of PHAse Diagram (CALPHAD) method was carried out to understand the effect of important minor oxides (i.e. $\mathrm{SO}_{3}, \mathrm{Na}_{2} \mathrm{O}, \mathrm{K}_{2} \mathrm{O}, \mathrm{TiO}_{2}, \mathrm{MgO}$ ) and important mineralizers (i.e., $\mathrm{CaF}_{2}, \mathrm{AlF}_{3}, \mathrm{MgSiF}_{6}, \mathrm{Na}_{2} \mathrm{SiF}_{6}, \mathrm{CaCl}_{2}, \mathrm{ZnO}, \mathrm{CaSO}_{4}$ ) on Portland cement during clinkerization. The result obtained via CALPHAD method was found to be in agreement with the data derived from XRD-Rietveld analysis. Phase evolution diagram has been simulated to study the complex thermochemical reactions and phase formation occurring during cement clinkerization. In addition to this, effect of individual minor oxides and mineralizers on phase evolution and clinkerization temperature was studied extensively to understand their effect on major phase formation.
\end{abstract}

Keywords CALPHAD $\cdot$ Cement $\cdot$ Minor oxide $\cdot$ Mineralizers $\cdot$ FactSage

\section{Introduction}

The phase evolution in Portland cement involves very complicated thermochemical reactions occurring during clinkerization which is energy intensive high temperature operation $\left(1400-1450^{\circ} \mathrm{C}\right)$. The raw materials used for Portland cement contains several minor oxides (i.e., $\mathrm{MgO}$, $\mathrm{Na}_{2} \mathrm{O}, \mathrm{TiO}_{2}, \mathrm{ZnO}, \mathrm{MnO}, \mathrm{K}_{2} \mathrm{O}, \mathrm{P}_{2} \mathrm{O}_{5}$ ) along with main oxide components such as $\mathrm{CaO}, \mathrm{Al}_{2} \mathrm{O}_{3} \mathrm{SiO}_{2}$ and $\mathrm{Fe}_{2} \mathrm{O}_{3}$ (C, $\mathrm{A}, \mathrm{S}$ and $\mathrm{F}) ; \mathrm{SO}_{3}$ is also infused from combustion fuel in cement during processing [1]. Mineralizers are sometimes added to raw mix in an effort to reduce the process temperature to achieve cost effective production [2-4]. These minor oxides and mineralizers have significant effect on phase formation.

The phases formed during clinkerization process are alite $\left(C_{3} S\right)$, belite $\left(C_{2} S\right)$, aluminate $\left(C_{3} A\right)$ and ferrite based solid solution $\left(\mathrm{C}_{4} \mathrm{AF}\right)$ via reaction among $\mathrm{CaO}, \mathrm{SiO}_{2}, \mathrm{Fe}_{2} \mathrm{O}_{3}$ and $\mathrm{Al}_{2} \mathrm{O}_{3}$ [5]. These phases are very much critical for the development of strength of cement during hydration. $C_{3} S$ and $\mathrm{C}_{2} \mathrm{~S}$ are responsible for the development of early and later strength, respectively, whereas $C_{3} A$ has a very important role in controlling setting time. $\mathrm{C}_{4} \mathrm{AF}$ plays the role of colourant in cement and flux for the reduction of process temperature. The chemical and mineralogical names along with the chemical formula and their range of occurrence in Portland cement are given in Table 1. The major phases formed during clinkerization is normally calculated by using well-known Bogue's equation (Eqs. 1-4) [5] to ensure the quality of final product.

$$
\begin{aligned}
\mathrm{C}_{3} \mathrm{~S}= & 4.0710 \times \mathrm{CaO}-7.6024 \times \mathrm{SiO}_{2}-1.4297 \\
& \times \mathrm{Fe}_{2} \mathrm{O}_{3}-6.7187 \times \mathrm{Al}_{2} \mathrm{O}_{3}-2.852 \times \mathrm{SO}_{3} \\
\mathrm{C}_{2} \mathrm{~S}= & 2.867 \times \mathrm{SiO}_{2}-0.7544 \times \mathrm{C}_{3} \mathrm{~S} \\
\mathrm{C}_{3} \mathrm{~A}= & 2.6504 \times \mathrm{Al}_{2} \mathrm{O}_{3}-1.6920 \times \mathrm{Fe}_{2} \mathrm{O}_{3}
\end{aligned}
$$

A. Tazuddin, tzddn97@gmail.com | ${ }^{1}$ Aditya Birla Science and Technology Co. Pvt. Ltd., Navi Mumbai, India. 
Table 1 Range of major phases seen in Portland cement clinker

\begin{tabular}{llllll}
\hline Mineral name & Alite & Belite & Aluminate & Ferrite & Lime \\
\hline Chemical name & Tricalcium silicate & Dicalcium silicate & Tricalcium aluminate & Tetracalcium aluminoferrite & Calcium oxide \\
Chemical formula & $\mathrm{Ca}_{3} \mathrm{SiO}_{5}$ & $\mathrm{Ca}_{2} \mathrm{SiO}_{4}$ & $\mathrm{Ca}_{3} \mathrm{Al}_{2} \mathrm{O}_{6}$ & $\mathrm{Ca}_{2} \mathrm{AlFeO}_{5}$ & $\mathrm{CaO}$ \\
Oxide formula & $3 \mathrm{CaO} \cdot \mathrm{SiO}_{2}$ & $2 \mathrm{CaO} \cdot \mathrm{SiO}_{2}$ & $3 \mathrm{CaO} \cdot \mathrm{Al}_{2} \mathrm{O}_{3}$ & $4 \mathrm{CaO}_{2} \mathrm{Al}_{2} \mathrm{O}_{3} \cdot \mathrm{Fe}_{2} \mathrm{O}_{3}$ & $\mathrm{CaO}$ \\
Cement notation & $\mathrm{C}_{3} \mathrm{~S}$ & $\mathrm{C}$ & $\mathrm{C}$ & $\mathrm{C}_{4} \mathrm{AF}$ & $\mathrm{C}$ \\
wt\% in clinker & $50-70$ & $12-25$ & $2-6$ & $10-17$ & $0-2$ \\
\hline
\end{tabular}

$\mathrm{C}_{4} \mathrm{AF}=3.0432 \times \mathrm{Fe}_{2} \mathrm{O}_{3}$

It is very important to have control over processing to maintain all the phases in a defined range for achieving desirable properties in final product. The effect of all the major oxides on phase formation is very much critical. The authors have already shown the thermodynamic analysis of effect of major oxides on phase formation in a previous report [6]. The aim of the current work is to carry out a systematic thermodynamic study on the effect of minor oxides and mineralizers on phase formations.

The minor oxides and mineralizers have been reported to have significant effects on cement properties [3, 7, 8]. The controlled presence of these constituents in raw materials is beneficial in aiding phase formation, reaction kinetics, refractory life, fuel efficiency and hydration during application [7, 9-11].

As cement clinkerization process requires to form sufficient ionic liquid (25-30\%) for desirable phase formation, the temperature requirement is very high $\left(1400-1450{ }^{\circ} \mathrm{C}\right)$ for pure system. This temperature is brought down with the addition of mineralizer (i.e., $\mathrm{CaF}_{2}, \mathrm{AlF}_{3}, \mathrm{MgSiF}_{6}, \mathrm{Na}_{2} \mathrm{SiF}_{6}$, $\mathrm{CaCl}_{2}, \mathrm{ZnO} \mathrm{CaSO}_{4}$ etc.[12, 13]. Thus, the presence of mineralizer helps in achieving cost effectiveness of the process. Therefore, it is very important to study the interactions of these minor constituents with the major oxides during clinkerization process in order to understand their ultimate effect on phase formation.

A complete thermodynamic study is a prime requirement of this system to have a complete understanding on the phase formation. However, available binary or ternary phase diagrams are not enough to study such complex multicomponent systems (> 5 component) since it cannot consider the effect of the entire component together. Therefore, in the present study computational thermodynamics based CALPHAD (CALculation of PHAse Diagram) [14] method has been extensively used to study the phase evaluation at different thermodynamic conditions. Till date, there is no report available on such a study using CALPHAD.

CALPHAD is advanced computational mathematics based thermodynamic calculation method to calculate or predict phase equilibria $[15,16]$. It uses available experimental or theoretical thermodynamic data of lower order systems and extrapolates them to higher order systems using various well established Gibbs free energy models at a particular temperature ( $T$ ) and pressure (P). Finally, Gibbs free energy minimization technique is applied to available phases to reveal the stable phases at a particular equilibrium condition ( $T$ and $P$ ) [16]. Nowadays many commercial and open source software such as, FactSage [17], Thermo-Calc [18] and MTDATA [19] are available to perform the calculation.

\section{Methodology}

In current investigation, all the thermodynamic calculations were carried out using FactSage 7.3 software with FToxid database [17]. To validate the FactSage data first, three different raw mixes were prepared by mixing and grinding of Limestone, Bauxite, Laterite and Lithomarge in proper proportions. Then, the raw mix was fired to produce clinker in a platinum crucible using Carbolite DownHearth Furnace at $1450^{\circ} \mathrm{C}$ for $1 \mathrm{~h}$ followed by air quenching at $1300{ }^{\circ} \mathrm{C}$. The clinkers were analyzed by Bruker S8-TIGER X-ray Fluorescence (XRF) to study the chemical composition. Finally, it was also analyzed by using Bruker's D8 advanced diffractometer (XRD) with $\mathrm{C} u-K_{\alpha}$ radiation having wavelength $(\lambda) 0.154056 \mathrm{~nm}$. Rietveld analysis was carried out using TOPAS XRD software [20]. The CALPHAD result was then compared with XRD data and Bogue's calculations [21].

To see the phase evolution, phase evaluation diagram was created using FactSage for the XRF composition in a temperature range $700-1500{ }^{\circ} \mathrm{C}$ using composition of Sample-3. The microstructure of the same clinker was also studied using Optical microscopy and BSE-SEM imaging with point EDS and EDS mapping.

To study the effect of individual minor oxides, a reference standard composition of $\mathrm{C}-\mathrm{A}-\mathrm{S}-\mathrm{F}-\mathrm{M}$ system was considered (given in Table 2 ) and minor oxides were added in the $\mathrm{C}-\mathrm{A}-\mathrm{S}-\mathrm{F}-\mathrm{M}$ system with various proportions to study their effect within a particular temperature range. All the minor oxides were varied within a range given in the Table 3. Similarly, the effects of important mineralizers 
Table 2 Baseline raw mix composition of major oxides used to study effect of minor oxides and mineralizers

\begin{tabular}{llllll}
\hline Oxides & $\mathrm{CaO}$ & $\mathrm{SiO}_{2}$ & $\mathrm{Fe}_{2} \mathrm{O}_{3}$ & $\mathrm{Al}_{2} \mathrm{O}_{3}$ & $\mathrm{MgO}$ \\
\hline $\mathrm{Wt}(\%)$ & 66.46 & 21.48 & 5.01 & 5.45 & 1.6 \\
\hline
\end{tabular}

Table 3 Range of oxides considered to study the effect on phase formation

\begin{tabular}{lccccc}
\hline Oxides & $\mathrm{MgO}$ & $\mathrm{SO}_{3}$ & $\mathrm{Na}_{2} \mathrm{O}$ & $\mathrm{K}_{2} \mathrm{O}$ & $\mathrm{TiO}_{2}$ \\
\hline Range calculated (wt\%) & $1-6$ & $1-5$ & $0-1$ & $0-1$ & $1-3$ \\
\hline
\end{tabular}

$\left(\mathrm{CaF}_{2}, \mathrm{AlF}_{3}, \mathrm{MgSiF}_{6}, \mathrm{Na}_{2} \mathrm{SiF}_{6}, \mathrm{CaCl}_{2}, \mathrm{ZnO}\right.$ and $\left.\mathrm{CaSO}_{4}\right)$ on phase formation and clinkerization temperature have been calculated using equilibrium module of FactSage software. Finally, OriginLab 2017 [22] software was used to draw all the plots using the data obtained by CALPHAD calculation.

\section{Results and discussion}

Table 4 shows the chemical analysis result of the prepared clinkers obtained by the XRF-chemical analysis. Table 5 displays the percentage of different phases in three clinker samples obtained by different methods such as, CALPHAD calculation, Bogue's calculation and XRD-Rietveld method. Fitting parameters of XRD-Rietveld analysis $\left(R_{w p}\right.$ and $\left.G_{\text {of }}\right)$ are also given in Table 5. To calculate the stable phases using CALPHAD, $\mathrm{C}_{3} \mathrm{~S}, \mathrm{C}_{2} \mathrm{~S}$, $\mathrm{CaO}$ and $\mathrm{MgO}$ was calculated at the quenching temperature $\left(1300^{\circ} \mathrm{C}\right)$ and $\mathrm{C}_{3} \mathrm{~A}$ and $\mathrm{C}_{4} \mathrm{AF}$ was calculated at $700^{\circ} \mathrm{C}$ since they are not stable at $1300^{\circ} \mathrm{C}$. All the solid solutions of $\mathrm{CaO}-\mathrm{Al}_{2} \mathrm{O}_{3}-\mathrm{Fe}_{2} \mathrm{O}_{3}$ that are stable at $700{ }^{\circ} \mathrm{C}$ are considered as $\mathrm{C}_{4} \mathrm{AF}$. It can be observed that $\mathrm{C}_{3} \mathrm{~S}$ prediction in CALPHAD method is very close to the XRD-Rietveld data both for Sample-1, Sample-2 and Sample-3. Prediction of Bogue equation is also very close to the XRD result. For $\mathrm{C}_{2} \mathrm{~S}$ prediction, CALPHAD result showed good match with the XRD-Rietveld data for all three samples. But, $\mathrm{C}_{2} \mathrm{~S}$ predicted by Bogue's equation is $4-5 \%$ high compared to actual XRD-Rietveld data. $C_{3} A$ predicted by CALPHAD is also very close to the $X R D$ result but, $C_{3} A$ predicted by Bogue's equation is much higher in Sample- 2 and Sample-3 compared to the XRD result. $C_{4} A F$ predicted by the CALPHAD is also very close to the XRD-Rietveld result but $C_{4} A F$ predicted by the CALPHAD is $2-5 \%$ less compared to the XRD-Rietveld result. Above result shows that, CALPHAD prediction data is very close to the actual experimental data which is not always true for Bouge's equation since it does not consider the effects of all the oxides and temperature [5].

From the above discussion, it can be concluded that the CALPHAD can precisely predict the cement phases at a given condition. In addition, CALPHAD method has a spin off benefit of calculating phase at any equilibrium conditions (temperature, pressure) [15]. So, CALPHAD can be used to study the phase evolution with increasing temperature and to understand the role of different important minor oxides in phase formation.
Table 4 Chemical analysis (XRF) of clinker synthesized in lab

\begin{tabular}{lllllllll}
\hline Oxides & $\mathrm{CaO}$ & $\mathrm{SiO}_{2}$ & $\mathrm{Fe}_{2} \mathrm{O}_{3}$ & $\mathrm{Al}_{2} \mathrm{O}_{3}$ & $\mathrm{MgO}$ & $\mathrm{K}_{2} \mathrm{O}$ & $\mathrm{Na}_{2} \mathrm{O}$ & $\mathrm{SO}_{3}$ \\
\hline Sample 1 & 65.87 & 22.12 & 4.70 & 5.86 & 0.77 & 0.24 & 0.1 & 0.31 \\
Sample 2 & 66.56 & 22.21 & 4.03 & 5.22 & 0.34 & 0.22 & 0.16 & 1.20 \\
Sample 3 & 62.1 & 20.7 & 4.10 & 5.02 & 5.73 & 0.87 & 0.17 & 1.3 \\
\hline
\end{tabular}

Table 5 Phase analysis result of clinker samples obtained by different method

\begin{tabular}{|c|c|c|c|c|c|c|c|c|c|}
\hline Temperature & Method & $\mathrm{C}_{3} \mathrm{~S}(\mathrm{wt} \%)$ & $\mathrm{C}_{2} \mathrm{~S}(\mathrm{wt} \%)$ & $\mathrm{C}_{3} \mathrm{~A}(\mathrm{wt} \%)$ & $\mathrm{C}_{4} \mathrm{AF}(\mathrm{wt} \%)$ & $\mathrm{MgO}$ (wt\%) & $\mathrm{CaO}(\mathrm{wt} \%)$ & $\mathrm{R}_{\mathrm{wp}}$ & $\mathrm{G}_{\mathrm{of}}$ \\
\hline \multirow[t]{3}{*}{ Sample-1 } & CALPHAD & 55.79 & 20.17 & 5.21 & 16.91 & 0.16 & 0 & - & - \\
\hline & Bogue & 53.02 & 23.42 & 7.58 & 14.30 & - & - & - & - \\
\hline & Rietveld & 54.5 & 19.7 & 8.4 & 16.2 & 0 & 1.2 & 7.25 & 7.85 \\
\hline \multirow[t]{3}{*}{ Sample-2 } & CALPHAD & 59.85 & 17.23 & 4.79 & 16.21 & 0 & 0 & - & - \\
\hline & Bogue & 57.86 & 20.03 & 7.02 & 12.26 & - & - & - & - \\
\hline & Rietveld & 61.1 & 16.8 & 4.6 & 17.7 & 0 & 0 & 8.31 & 8.69 \\
\hline \multirow[t]{3}{*}{ Sample-3 } & CALPHAD & 56.99 & 14.35 & 2.25 & 18.68 & 5.12 & 0 & - & - \\
\hline & Bogue & 52.14 & 20.01 & 6.37 & 12.48 & - & - & - & - \\
\hline & Rietveld & 55.9 & 15.7 & 1.0 & 17.7 & 6.3 & 0.6 & 7.40 & 8.06 \\
\hline
\end{tabular}


Figure 1 displays the temperature vs phase fraction diagram generated by CALPHAD method in the temperature range of $700-1500^{\circ} \mathrm{C}$ for the composition of Sample-3 given in Table 2. Figure 1 shows during clinkerization temperature $\left(1400-1450{ }^{\circ} \mathrm{C}\right)$, the stable phases are $C_{3} S, C_{2} S$, unreacted $\mathrm{MgO}$ and ionic liquid. During cooling, ionic liquid reduces while $\mathrm{C}_{2} \mathrm{~S}$ and $\mathrm{C}_{3} \mathrm{~S}$ phase increases till $1300^{\circ} \mathrm{C}$. Below $1300^{\circ} \mathrm{C}, \mathrm{C}_{3} \mathrm{~S}$ is not stable and it dissociates into $\mathrm{C}_{2} \mathrm{~S}$ and $\mathrm{CaO}$ as shown in Fig. 1. Below $1280-1290^{\circ} \mathrm{C}$, ionic liquid phase separation occurs and another solid solution phase i.e. $\mathrm{C}_{4} \mathrm{AF}$ starts forming. Below $1050-1100^{\circ} \mathrm{C}, \mathrm{C}_{3} \mathrm{~A}$ crystallizes out from remaining ionic liquid and finally remaining liquid solidifies during cooling depending on the quenching rate.

This diagram is very important to understand the phase formation route during heating in $\mathrm{C}-\mathrm{A}-\mathrm{S}-\mathrm{F}-\mathrm{M}$ system. It also shows that the quenching is necessary to get $C_{3} S$ phase after cooling as $\mathrm{C}_{3} \mathrm{~S}$ phase is stable above $1300^{\circ} \mathrm{C}$. This graph can also be useful in determining the maximum burning zone temperate of the rotary kiln to operate the

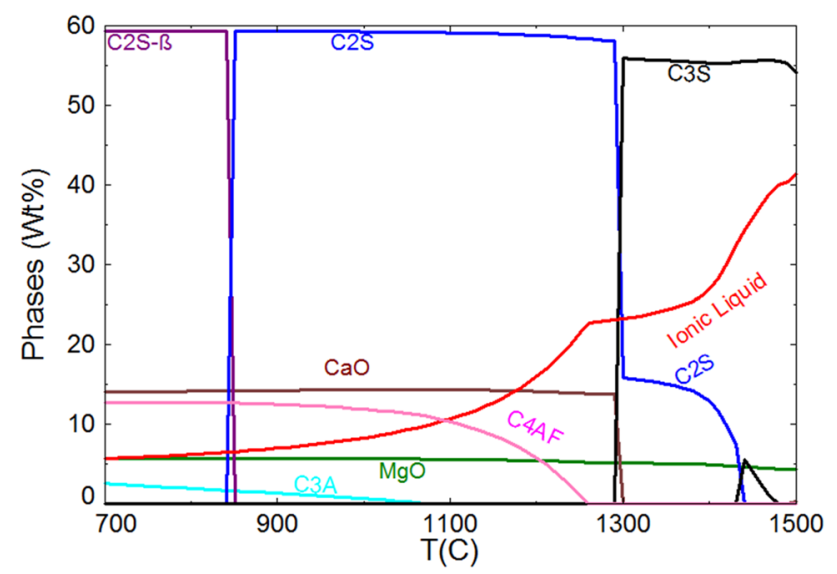

Fig. 1 Temperature vs. phase evolution diagram for Sample-3

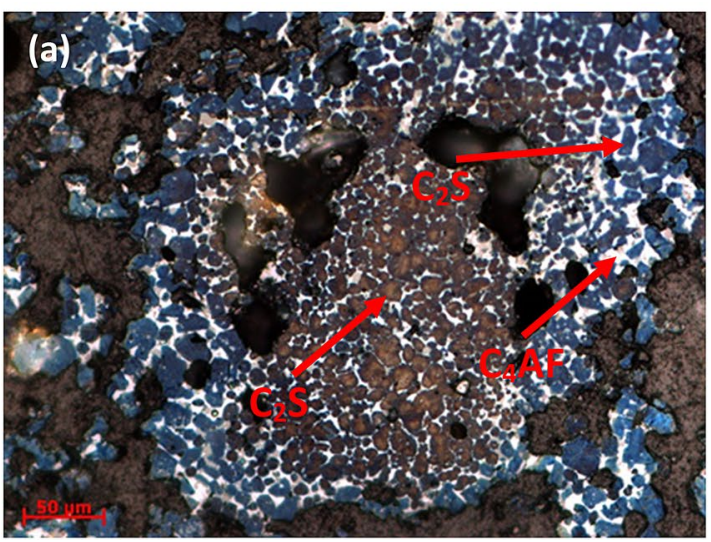

same safely within a maximum allowed ionic liquid percentage. For an instance, if the permissible limit of ionic liquid in a rotary kiln is $28 \mathrm{wt} \%$, the maximum furnace temperature should not exceed $1430{ }^{\circ} \mathrm{C}$ for the given raw mix composition of Sample-3 as suggested by the Fig. 1 . Similarly, maximum permissible calciner temperature can be determined from this graph to avoid ionic liquid phase formation in the calciner.

The Optical microscopy image of the above clinker (sample-3) along with the XRD patter is also shown in Fig. 2. It shows that the microstructure constitutes of three major phases, $C_{3} S$ phase with hexagonal grain, $C_{2} S$ phase with rounded grain and bright $\mathrm{C}_{4} \mathrm{AF}$ matrix. The result of XRD analysis is already shown in Table 5 . To identify the phases in microstructure, EDS mapping and Point EDS was carried out. Elemental distribution in the microstate along with BSE image is shown in Fig. 3. It shows that, bright matrix regions are rich in $\mathrm{Al}$ and Fe which indicates that it is $\mathrm{C}_{4} \mathrm{AF}$. Periclase are present as $\mathrm{MgO}$ cluster which appears to be dark in SEM image. Major regions are populated with $\mathrm{Ca}$ and $\mathrm{Si}$ which indicates $\mathrm{C}_{3} \mathrm{~S}$ and $\mathrm{C}_{2} \mathrm{~S}$ consist of major proportions. Average compositions of different phase obtained by EDS point analysis are also given in Table 6 .

Figure 4 shows the effect of $\mathrm{SO}_{3}$ on the major phase formation of $\mathrm{C}-\mathrm{A}-\mathrm{S}-\mathrm{F}-\mathrm{M}$ system. $\mathrm{SO}_{3}$ increases the $\mathrm{C}_{2} \mathrm{~S}$ and decreases $\mathrm{C}_{3} \mathrm{~S}$ above $1300^{\circ} \mathrm{C}$ as shown in Figs. 4a, b. But, above $1450^{\circ} \mathrm{C}, \mathrm{C}_{2} \mathrm{~S}$ decreases suddenly as it dissolves into the ionic liquid. The reduction of $\mathrm{C}_{2} \mathrm{~S}$ above $1450{ }^{\circ} \mathrm{C}$ directly depends on the $\mathrm{SO}_{3}$ content in the composition as shown in the Fig. 4. With increasing $\mathrm{SO}_{3}$ in the composition, the rate of dissolution increases and the $\mathrm{C}_{2} \mathrm{~S}$ decreases rapidly. A minute presence of $\mathrm{SO}_{3}(\sim 0.5 \%)$ can reduce the ionic liquid formation temperature by $\sim 20^{\circ} \mathrm{C}$. At lower temperature, $\mathrm{SO}_{3}$ does not have much effect on ionic liquid formation. However, at very higher temperature $\left(\geq 1450^{\circ} \mathrm{C}\right) \mathrm{SO}_{3}$ significantly increases the ionic liquid content by assisting the dissolution of $\mathrm{C}_{2} \mathrm{~S}$ into the ionic

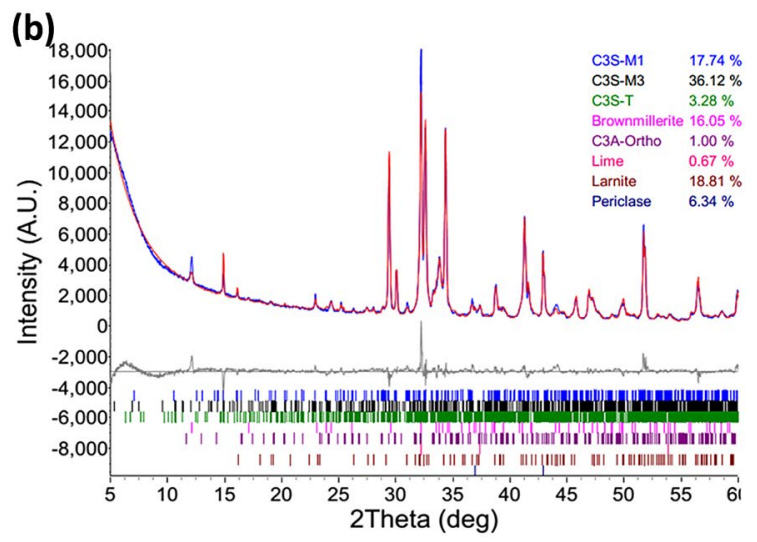

Fig. 2 a Optical microscopy image and $\mathbf{b}$ XRD-Rietveld analysis image of Clinker Sample-3 

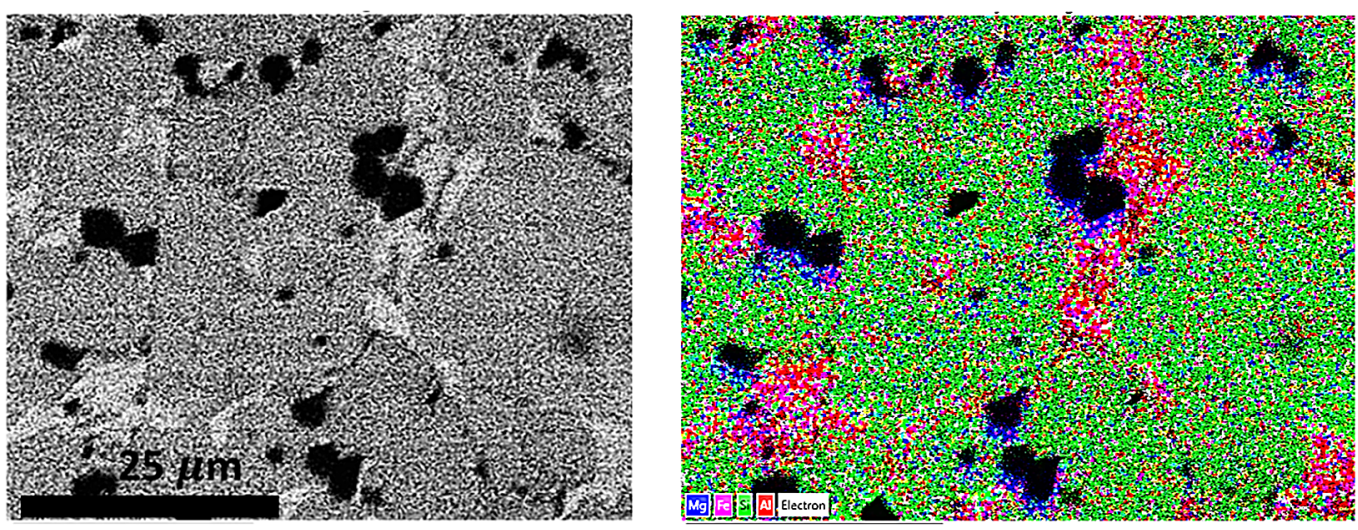

$\mathrm{Ca}$

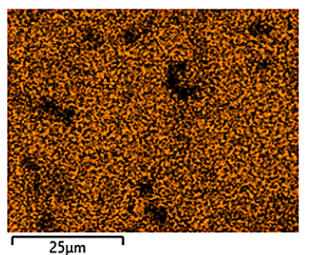

$\mathrm{Si}$

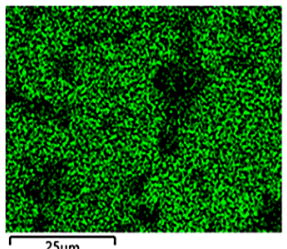

$\mathrm{Fe}$

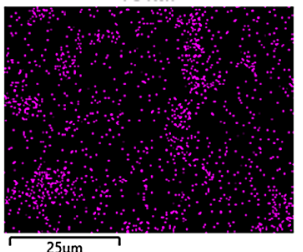

$\mathrm{Al}$

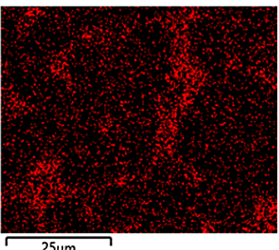

$\mathrm{Mg}$

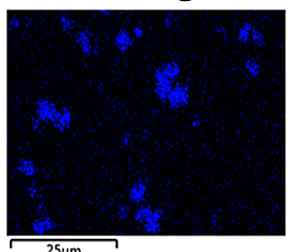

Fig. 3 BSE-SEM images, EDS-mapping and Elemental distribution map of Clinker Sample-3

Table 6 Average composition of different phases obtained by EDS point analysis

\begin{tabular}{llrrrrrrr}
\hline $\mathrm{Wt} \%$ & $\mathrm{CaO}$ & $\mathrm{Al}_{2} \mathrm{O}_{3}$ & $\mathrm{Fe}_{2} \mathrm{O}_{3}$ & $\mathrm{MgO}$ & $\mathrm{SiO}_{2}$ & $\mathrm{SO}_{3}$ & $\mathrm{~K}_{2} \mathrm{O}$ & $\mathrm{Na}_{2} \mathrm{O}$ \\
\hline $\mathrm{C}_{3} \mathrm{~S}$ & 70.95 & 0.94 & 0.81 & 3.14 & 23.91 & 0.11 & 0.15 & 0.00 \\
$\mathrm{C}_{2} \mathrm{~S}$ & 66.51 & 1.17 & 0.53 & 0.54 & 29.71 & 0.85 & 0.17 & 0.52 \\
$\mathrm{C}_{4} \mathrm{AF}$ & 64.35 & 13.12 & 12.46 & 4.20 & 5.67 & 0.20 & 0.00 & 0.00 \\
\hline
\end{tabular}

Fig. 4 Effect of $\mathrm{SO}_{3}$ on phase formation in $\mathrm{C}-\mathrm{A}-\mathrm{S}-\mathrm{F}-\mathrm{M}$ system in temperature range of $1100^{\circ} \mathrm{C}$ to $1500^{\circ} \mathrm{C}$; a effect on $\mathrm{C}_{2} \mathrm{~S}$, $\mathbf{b}$ effect on $\mathrm{C}_{3} \mathrm{~S}$ and $\mathbf{c}$ effect on liquid phase
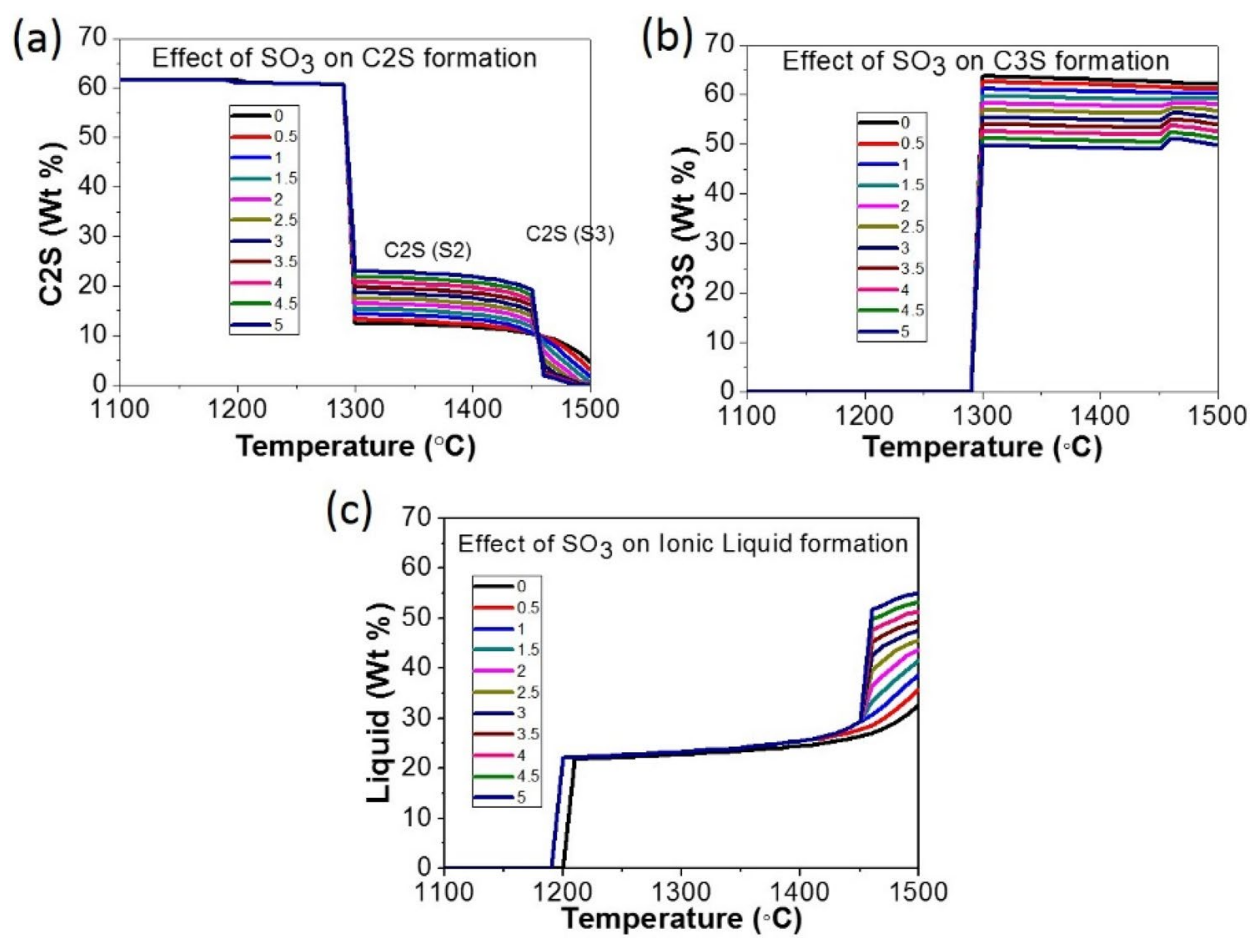
liquid as shown in Fig. 4c. So, if $\mathrm{SO}_{3}$ is high (>1.5 wt\%) in the raw mix, the maximum kiln temperature should be less than $1450^{\circ} \mathrm{C}$ to avoid the excess liquid formation in the kiln in order to avoid uncontrolled liquid formation in kiln. To understand the influence of $\mathrm{SO}_{3}$ in increasing $\mathrm{C}_{2} \mathrm{~S}$ and lowering $\mathrm{C}_{3} \mathrm{~S}$, the effect of $\mathrm{SO}_{3}$ on $\mathrm{CaO}-\mathrm{SiO}_{2}$ binary diagram was simulated which is illustrated in Fig. 5. It shows the overlapping of two $\mathrm{CaO}-\mathrm{SiO}_{2}$ binary phase diagrams, one is without $\mathrm{SO}_{3}$ (black) and other one is with $2 \% \mathrm{SO}_{3}$ (red). Figure $5 \mathrm{~b}$ is the magnified view of the area of interest of Fig. 5 a to present the effect of adding $2 \% \mathrm{SO}_{3}$ on $\mathrm{C}_{3} \mathrm{~S}$ and $\mathrm{C}_{2} \mathrm{~S}$ formation in the temperature range $1000-1800^{\circ} \mathrm{C}$. As it demonstrated, with the addition of $\mathrm{SO}_{3}$, the equilibrium line $P Q$ shifts to right $P^{\prime} Q$ '. Now the effect of shifting the line can be understood better by applying the Liver's rule in the phase diagram. When, $\mathrm{CaO} /\left(\mathrm{CaO}+\mathrm{SiO}_{2}\right)=0.7$, applying Liver's rule, the wt. percent of $\mathrm{C}_{3} \mathrm{~S}$ and $\mathrm{C}_{2} \mathrm{~S}$ without using $\mathrm{SO}_{3}$ is represented by $\frac{O R}{R S}$ and $\frac{O S}{R S}$ respectively. For the addition of $2 \% \mathrm{SO}_{3}$, the percentages of $\mathrm{C}_{3} \mathrm{~S}$ and $\mathrm{C}_{2} \mathrm{~S}$ are $\frac{O^{\prime} R^{\prime}}{R^{\prime} S^{\prime}}$ and $\frac{O^{\prime} S^{\prime}}{R^{\prime} S^{\prime}}$ respectively. The addition of $2 \%, \mathrm{SO}_{3}$ resulted decreases of $C_{3} S$ and increase of $C_{2} S$ since, $\frac{O^{\prime} R}{R^{\prime} S^{\prime}}<$ $\frac{O R}{R S}$ and $\frac{O^{\prime} S^{\prime}}{R^{\prime} S^{\prime}}>\frac{O S}{R S}$. The effect of $\mathrm{SO}_{3}$ on $C_{3} S$ and $C_{2} S$ obtained by CALPHAD agrees with the finding of W. Gutt et al. [23] and Horkoss et al. [24] as they also have reported that $\mathrm{SO}_{3}$ increases $\mathrm{C}_{2} \mathrm{~S}$ and decreases $\mathrm{C}_{3} \mathrm{~S}$ in the clinker. Li et al. [25] has also reported similar observation on $\mathrm{C}_{3} \mathrm{~S}$ and $\mathrm{C}_{2} \mathrm{~S}$.

Figure 6 displays the effect of $\mathrm{Na}_{2} \mathrm{O}$ on phase evolution of $\mathrm{C}-\mathrm{A}-\mathrm{S}-\mathrm{F}-\mathrm{M}$ system. It also has a negative effect on decreasing $\mathrm{C}_{2} \mathrm{~S}$ above $1290^{\circ} \mathrm{C}$. With increasing $\mathrm{Na}_{2} \mathrm{O}$, $\mathrm{C}_{3} \mathrm{~S}$ increases linearly as shown in Fig. 6b. But, at higher temperature $\left(>1450^{\circ} \mathrm{C}\right), \mathrm{C}_{3} \mathrm{~S}$ dissolves to form ionic liquid and $\mathrm{C}_{3} \mathrm{~S}$ decreases. The dissolution temperature and amount of dissolution also depends on $\mathrm{Na}_{2} \mathrm{O}$ content in the ionic liquid as shown in Fig. 6b. With increasing $\mathrm{Na}_{2} \mathrm{O}$, the dissolution temperature of $\mathrm{C}_{3} \mathrm{~S}$ decreases. The rate of dissolution also increases with increasing $\mathrm{Na}_{2} \mathrm{O}$ in cement raw mix. The proportion of ionic liquid phase which forms at low temperature, increases with increasing the proportion of $\mathrm{Na}_{2} \mathrm{O}$. Above $1450^{\circ} \mathrm{C}$, ionic liquid content suddenly increases due to dissolution of $\mathrm{C}_{3} \mathrm{~S}$ as described earlier. Figure $7 a, b$ shows the effect of increasing $\mathrm{Na}_{2} \mathrm{O}$ on $\mathrm{CaO}-\mathrm{SiO}_{2}$ binary phase diagram. Black and red colour curve represent binary diagram without $\mathrm{Na}_{2} \mathrm{O}$ and with $0.5 \% \mathrm{Na}_{2} \mathrm{O}$. Applying Liver rule, it can be seen that, with addition of $0.5 \% \mathrm{Na}_{2} \mathrm{O}, \mathrm{C}_{3} \mathrm{~S}$ increases and $\mathrm{C}_{2} \mathrm{~S}$ decreases as, $\frac{O^{\prime} R^{\prime}}{R^{\prime} S^{\prime}}>\frac{O R}{R S}$ and $\frac{O^{\prime} S^{\prime}}{R^{\prime} S^{\prime}}<\frac{O S}{R S}$. The CALPHAD results also matches with the experimental results as, it been proved earlier by experimental investigations that $\mathrm{Na}_{2} \mathrm{O}$ increases $\mathrm{C}_{3} \mathrm{~S}$ and decreases $C_{2} S$ [26-28].

Figure $8 \mathrm{a}-\mathrm{c}$ describes the influence of $\mathrm{K}_{2} \mathrm{O}$ in phase formation of Portland cement. With increasing $\mathrm{K}_{2} \mathrm{O}$ in C-A-S-F-M system, it has a significant effect in decreasing $\mathrm{C}_{2} \mathrm{~S}$ and increase of ionic liquid as shown in the Fig. $8 \mathrm{a}$ and c. Minute addition ( $0.05 \mathrm{wt} \%)$ of $\mathrm{K}_{2} \mathrm{O}$ reduces the ionic liquid formation temperature by $10-15^{\circ} \mathrm{C} . \mathrm{K}_{2} \mathrm{O}$ also has a marginal effect in increasing $\mathrm{C}_{3} \mathrm{~S}$. The root cause of increasing $\mathrm{C}_{3} \mathrm{~S}$ and decreasing $\mathrm{C}_{2} \mathrm{~S}$ can be seen form the binary diagram of $\mathrm{CaO}-\mathrm{SiO}_{2}$ as shown in Fig. $9 \mathrm{a}$ and $b$ Black and red line represents without addition of $\mathrm{K}_{2} \mathrm{O}$ and red line represents with addition of $0.5 \% \mathrm{~K}_{2} \mathrm{O}$. As the Fig. $9 \mathrm{~b}$ shows the effect of $\mathrm{K}_{2} \mathrm{O}$ on $\mathrm{CaO}-\mathrm{SiO}_{2}$ binary phase diagram is very much similar to the effect of $\mathrm{Na}_{2} \mathrm{O}$. It also increases $\mathrm{C}_{3} \mathrm{~S}$ and decreases $C_{2} S$ as $\frac{O^{\prime} R^{\prime}}{R^{\prime} S^{\prime}}>\frac{O R}{R S}$ and $\frac{O^{\prime} S^{\prime}}{R^{\prime} S^{\prime}}<\frac{O S}{R S}$. Although the effect of $\mathrm{K}_{2} \mathrm{O}$ on increasing $\mathrm{C}_{3} \mathrm{~S}$ and decreasing $\mathrm{C}_{2} \mathrm{~S}$ is not as strong as $\mathrm{Na}_{2} \mathrm{O}$ as, the shift of $P Q$ line to $P^{\prime} Q^{\prime}$ is less in case of $0.5 \% \mathrm{~K}_{2} \mathrm{O}$ addition as compared with $0.5 \% \mathrm{Na}_{2} \mathrm{O}$ addition.

Figure 10 depicts the effect of increasing $\mathrm{MgO}$ on the formation of $\mathrm{C}_{3} \mathrm{~S}_{2} \mathrm{C}_{2} \mathrm{~S}$ and ionic liquid phase. $\mathrm{MgO}$ has a nominal effect on decreasing $C_{2} S$ and increasing $C_{3} S$.

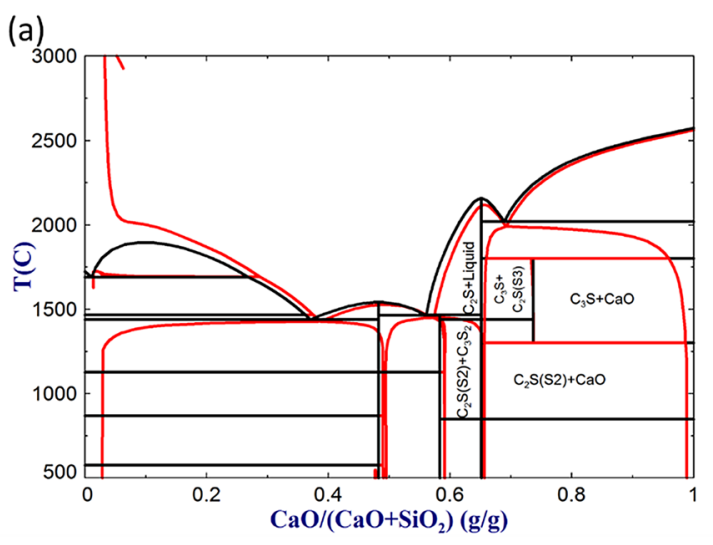

With $0 \mathrm{Wt} \% \mathrm{SO}_{3}$ (b)

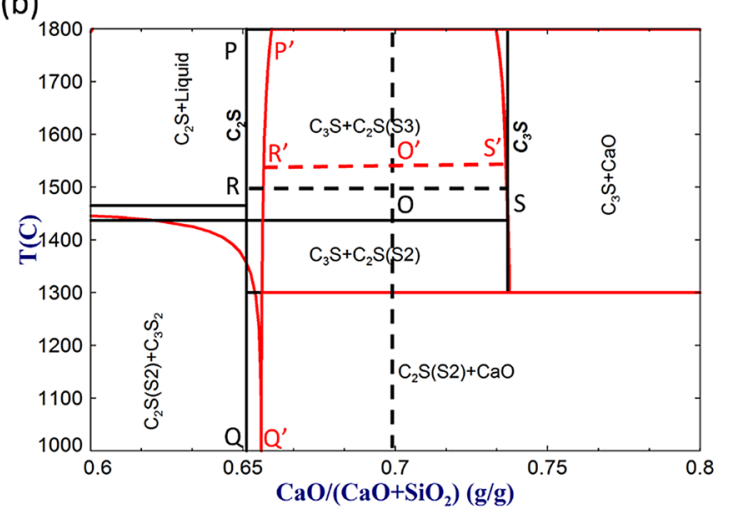

With $2 \mathrm{Wt} \% \mathrm{SO}_{3}$

Fig. 5 a Effect of addition of 2 wt. \% $\mathrm{SO}_{3}$ on the $\mathrm{CaO}-\mathrm{SiO}_{2}$ phase diagram. $\mathbf{b}$ Magnified view of effect of $\mathrm{SO}_{3}$ addition 

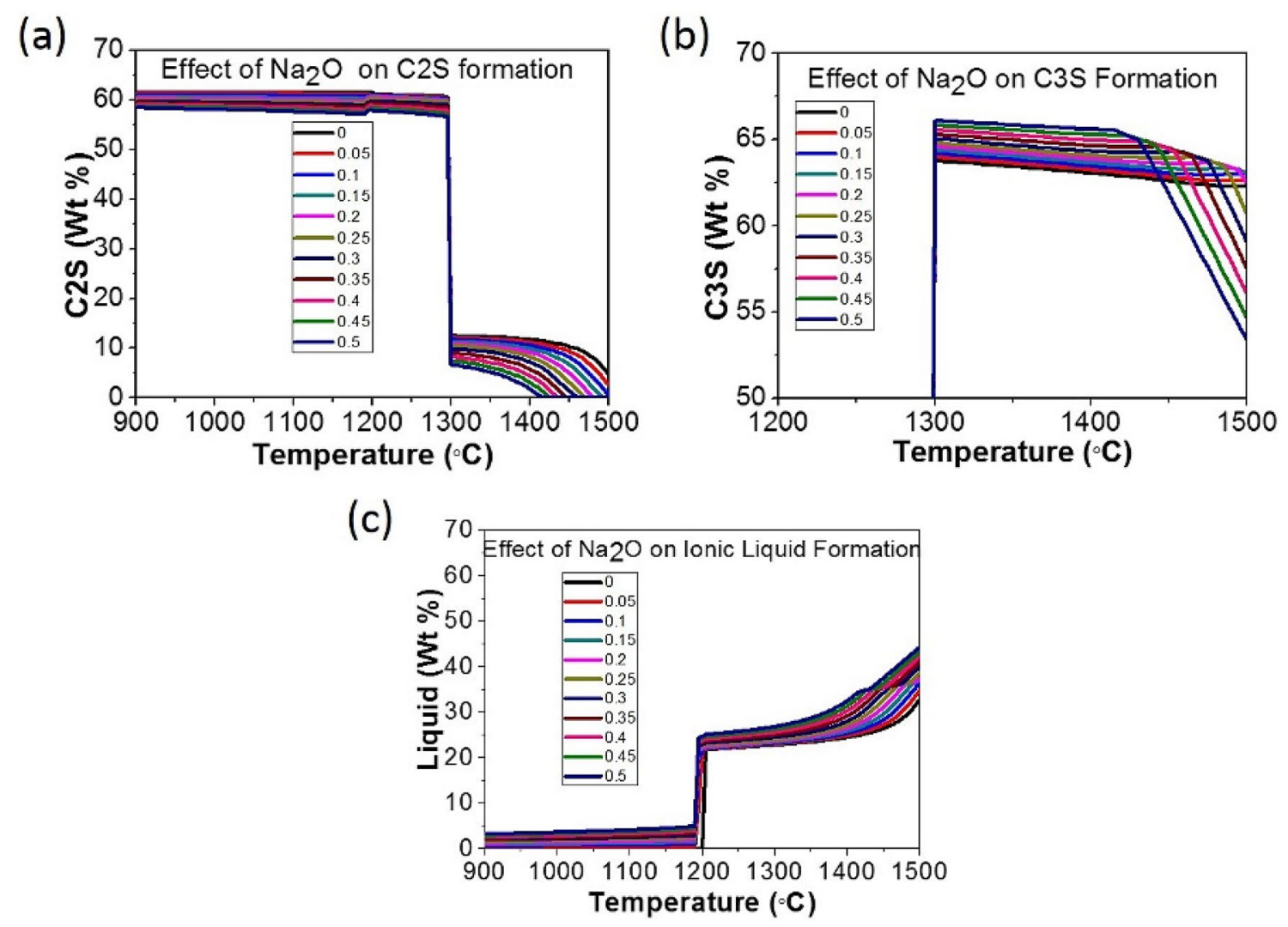

Fig. 6 Effect of $\mathrm{Na}_{2} \mathrm{O}$ on phase formation in $\mathrm{C}-\mathrm{A}-\mathrm{S}-\mathrm{F}-\mathrm{M}$ system in temperature range of $1100{ }^{\circ} \mathrm{C}$ to $1500{ }^{\circ} \mathrm{C}$; $\mathbf{a}$ effect on $\mathrm{C}_{2} \mathrm{~S}, \mathbf{b}$ effect on $\mathrm{C}_{3} \mathrm{~S}$ and $c$ effect on liquid phase
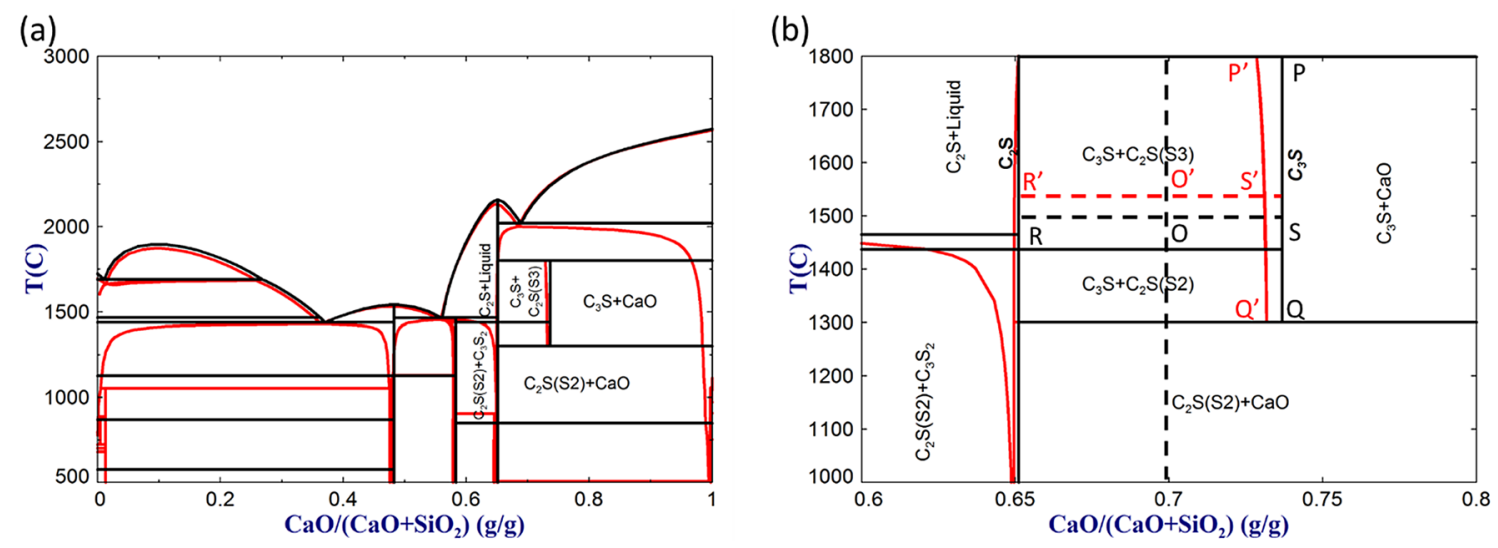

With $0 \mathrm{Wt} \% \mathrm{Na}_{2} \mathrm{O}$ With $0.5 \mathrm{Wt} \% \mathrm{Na}_{2} \mathrm{O}$

Fig. 7 a Effect of addition of $0.5 \mathrm{wt} \% \mathrm{Na}_{2} \mathrm{O}$ on the $\mathrm{CaO}-\mathrm{SiO}_{2}$ system, $\mathbf{b}$ magnified view of fig. a

Addition of $\mathrm{MgO}$ up to $1 \mathrm{wt} \%$ in raw mix can increase $\mathrm{C}_{3} \mathrm{~S}$ content by $\sim 2 \mathrm{wt} \%$. It reduces the ionic liquid formation temperature by $20^{\circ} \mathrm{C}$ but, it does not have significant role in increasing ionic liquid below $1400^{\circ} \mathrm{C}$. Although, it can assist in increasing ionic liquid above $1400^{\circ} \mathrm{C}$. Figure $10 \mathrm{~d}$ shows, higher amount of $\mathrm{MgO}(>1 \mathrm{wt} \%$ ) leads to the formation of periclase (free $\mathrm{MgO}$ ) which is partially dissolves with increasing temperature. If $\mathrm{MgO}$ is more than $1.5 \mathrm{wt} \%$, it can't dissolve completely into the ionic liquid phase even at $1400^{\circ} \mathrm{C}$ as a result, free $\mathrm{MgO}$ may be present as a form of periclase with other phases in the clinker. Free $\mathrm{MgO}$ and $\mathrm{CaO}$ are not desirable in the final product as it 
(a)

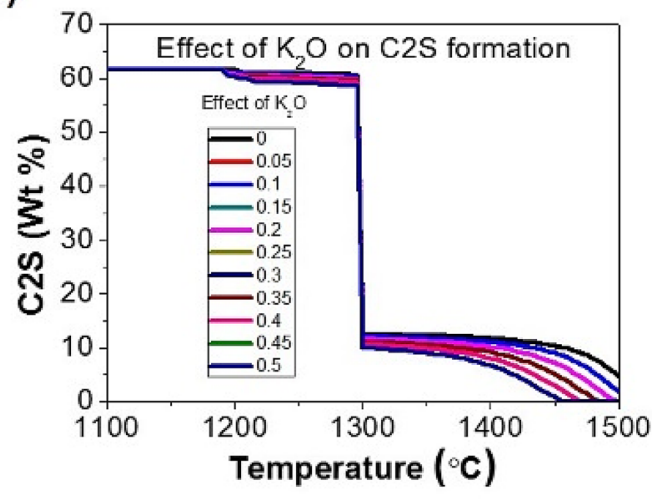

(b)

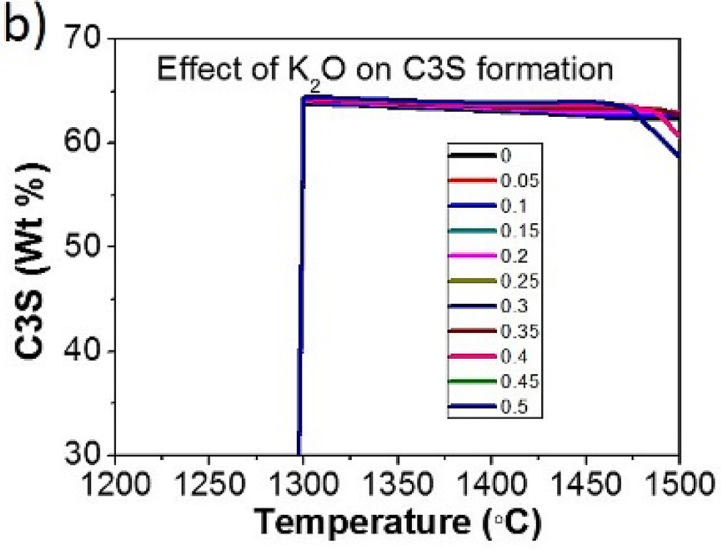

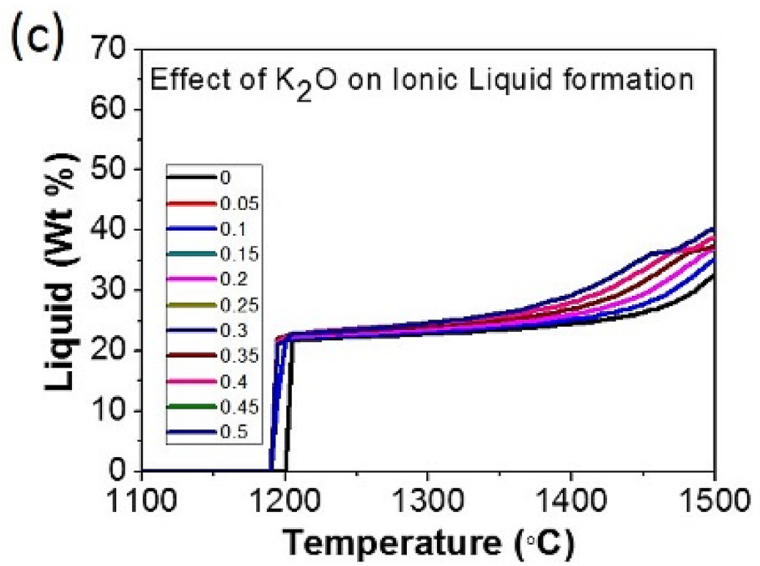

Fig. 8 Effect of $\mathrm{K}_{2} \mathrm{O}$ on phase formation in $\mathrm{C}-\mathrm{A}-\mathrm{S}-\mathrm{F}-\mathrm{M}$ system in temperature range of $1100{ }^{\circ} \mathrm{C}$ to $1500{ }^{\circ} \mathrm{C}$; $\mathbf{a}$ effect on $\mathrm{C}_{2} \mathrm{~S}$, b effect on $\mathrm{C}_{3} \mathrm{~S}$ and $\mathbf{c}$ effect on liquid phase

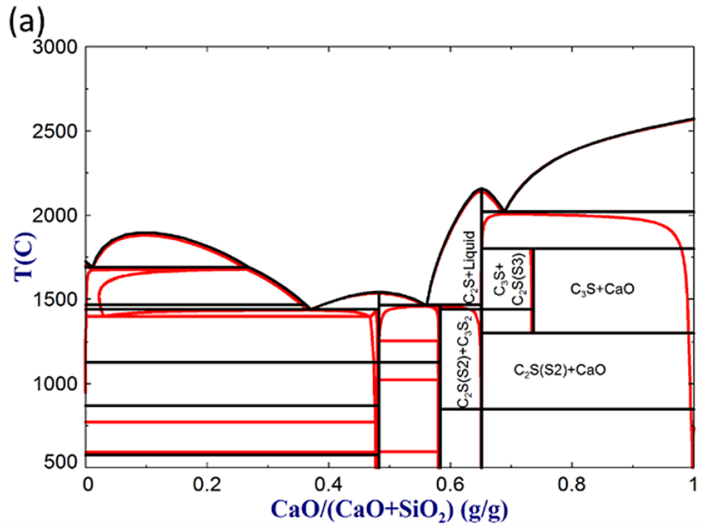

(b)

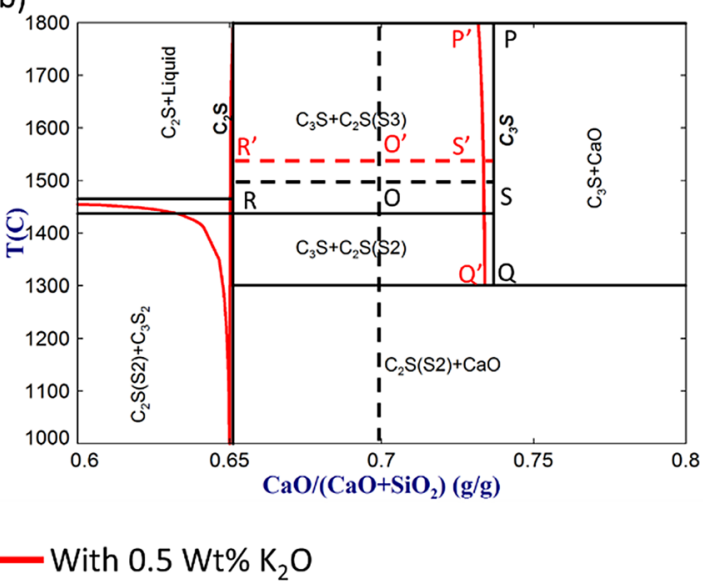

Fig. 9 a Effect of $\mathrm{K}_{2} \mathrm{O}$ on $\mathrm{CaO}-\mathrm{SiO}_{2}$ phase diagram, $\mathbf{b}$ magnified view of fig. a

causes expansion during hydration and generates crack after setting of cement.

Figure 11 depicts the effect of $\mathrm{TiO}_{2}$ on various phase formation. It significantly increases $\mathrm{C}_{2} \mathrm{~S}$ and decreases $\mathrm{C}_{3} \mathrm{~S}$ above $1290^{\circ} \mathrm{C}$. At lower temperature, it does not have any effect on the formation of ionic liquid. But, above $1350-1370{ }^{\circ} \mathrm{C}$, it significantly increases ionic liquid with increasing $\mathrm{TiO}_{2}$ as shown in Fig. 11c. Figure 12a, b show 


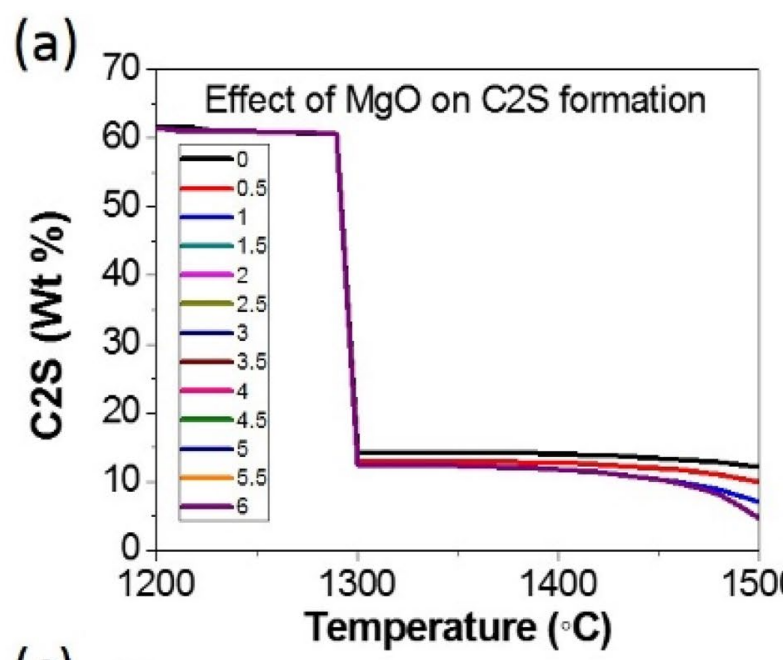

(b)
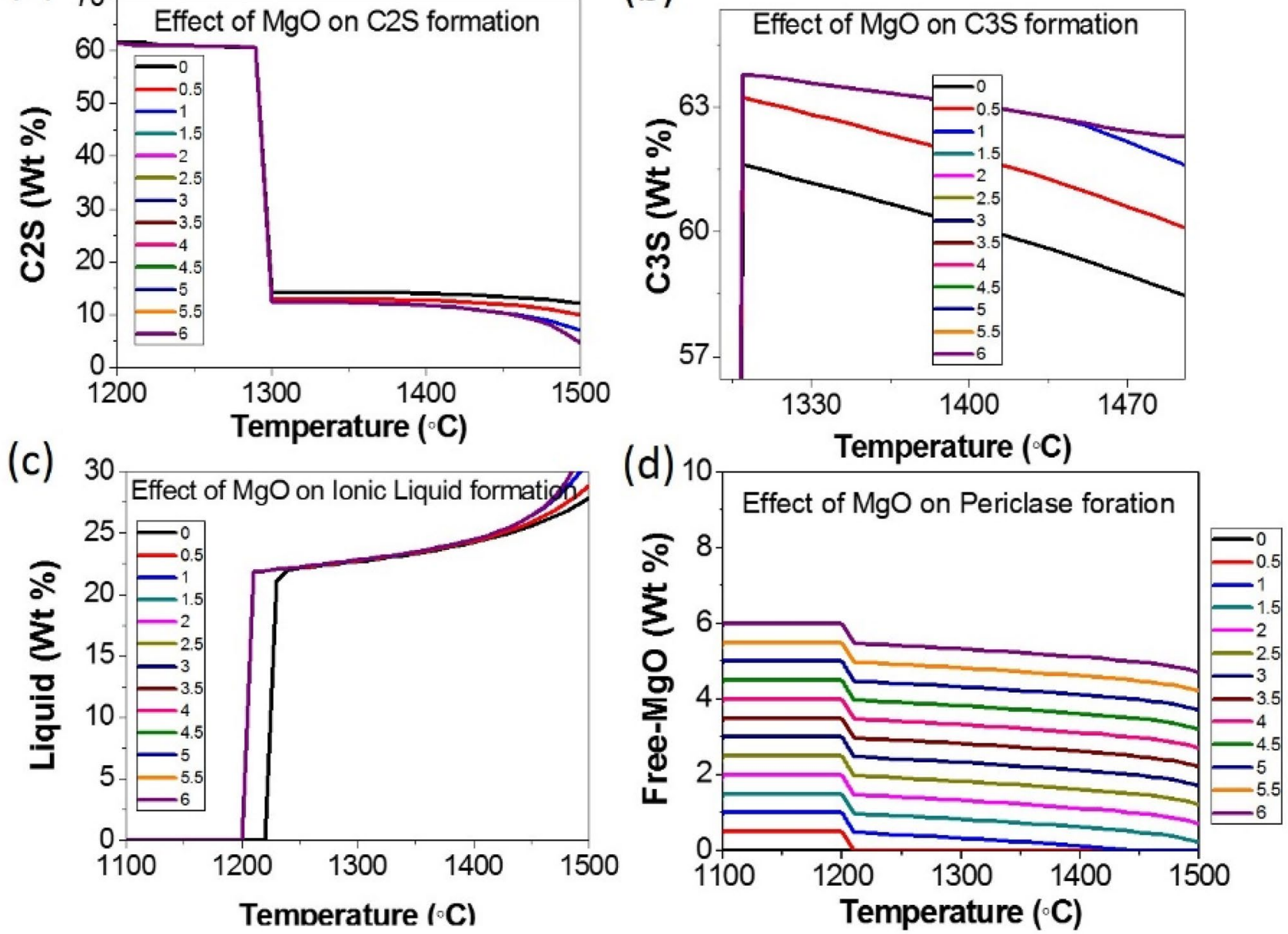

Fig. 10 Effect of $\mathrm{MgO}$ on phase formation in C-A-S-F-M system in temperature range of $1100^{\circ} \mathrm{C}$ to $1500{ }^{\circ} \mathrm{C} ; \mathbf{a}$ effect on $\mathrm{C}_{2} \mathrm{~S}, \mathbf{b}$ effect on $\mathrm{C}_{3} \mathrm{~S}$, c effect on liquid phase and $\mathbf{d}$ effect on Free MgO formation

the effect of $\mathrm{TiO}_{2}$ on $\mathrm{CaO}-\mathrm{SiO}_{2}$ binary phase diagram. It shows that at 2 wt $\% \mathrm{TiO}_{2}, \mathrm{C}_{3} \mathrm{~S}$ decreases and $\mathrm{C}_{2} \mathrm{~S}$ increases as $\frac{O^{\prime} R^{\prime}}{R^{\prime} S^{\prime}}<\frac{O R}{R S}$ and $\frac{O^{\prime} S^{\prime}}{R^{\prime} S^{\prime}}>\frac{O S}{R S}$. The amount of $\mathrm{TiO}_{2}$ in raw mix is also very critical as it has substantial effect on all the important phase formation. Although it helps in clinkerization by the formation of ionic liquid phase but, excess amount of $\mathrm{TiO}_{2}$ in raw mix can be detrimental as it leads to the lowering $\mathrm{C}_{3} \mathrm{~S}$ and also causing coating formation in the kiln because of excessive ionic liquid formation at high temperature. The result of CALPHAD found to be in line with the observations of many researchers as they also have reported that $\mathrm{TiO}_{2}$ increases the burnability of raw mix by increasing the ionic liquid phase and as a result the free lime decreases [28].

Figure 13 shows the effect of all the minor oxides on phase formation at $1450{ }^{\circ} \mathrm{C} . \mathrm{SO}_{3}$ increases ionic liquid phase up to $1 \%$ at $1450^{\circ} \mathrm{C}$ as shown here in Fig. 12a. $\mathrm{C}_{2} \mathrm{~S}$ increases linearly with increasing $\mathrm{SO}_{3}$ when it is more than $1 \%$ whereas, $C_{3} S$ decreases linearly with increasing
$\mathrm{SO}_{3}$. Ionic liquid increases with increasing $\mathrm{Na}_{2} \mathrm{O}$. But, the rate of increase of ionic liquid, decreases after $0.4 \%$ addition of $\mathrm{Na}_{2} \mathrm{O} . \mathrm{C}_{2} \mathrm{~S}$ decreases with increasing $\mathrm{Na}_{2} \mathrm{O}$ up to $0.3 \%$ then it saturates as shown in Fig. $13 \mathrm{~b}$. But, $\mathrm{C}_{3} \mathrm{~S}$ increases with increasing $\mathrm{Na}_{2} \mathrm{O}$ up to $0.4 \%$ and it reduces with increasing $\mathrm{Na}_{2} \mathrm{O}$. Similarly, with increasing $\mathrm{K}_{2} \mathrm{O}$, ionic liquid increases and $\mathrm{C}_{2} \mathrm{~S}$ decreases with a different pattern but, $\mathrm{C}_{3} \mathrm{~S}$ increases with increasing $\mathrm{K}_{2} \mathrm{O}$ as shown in Fig. $13 \mathrm{c}$. That is why alkalies $\left(\mathrm{Na}_{2} \mathrm{O}\right.$ and $\left.\mathrm{K}_{2} \mathrm{O}\right)$ play a critical role in deciding the strength of Portland cement. This effect is more prominent for $\mathrm{Na}_{2} \mathrm{O}$ as it is more effective in increasing $\mathrm{C}_{3} \mathrm{~S}$ and decreasing $\mathrm{C}_{2} \mathrm{~S}$ as shown in Fig. $13 \mathrm{~b}, \mathrm{c}$. Addition of $1 \mathrm{wt} \%$ of $\mathrm{MgO}$, can increase the ionic liquid content by $1 \%$, increases $\mathrm{C}_{3} \mathrm{~S}$ content by 3 wt $\%$ and decreases $\mathrm{C}_{2} \mathrm{~S}$ by $3 \%$. Beyond that, it does not have much effect on phase evolution at $1400{ }^{\circ} \mathrm{C}$. $\mathrm{TiO}_{2}$ has a major role in increasing ionic liquid and $\mathrm{C}_{2} \mathrm{~S}$ at $1450^{\circ} \mathrm{C}$ as shown in Fig. $13 \mathrm{e}$. But, it has a negative role in decreasing $\mathrm{C}_{3} \mathrm{~S}$ at this temperature. 

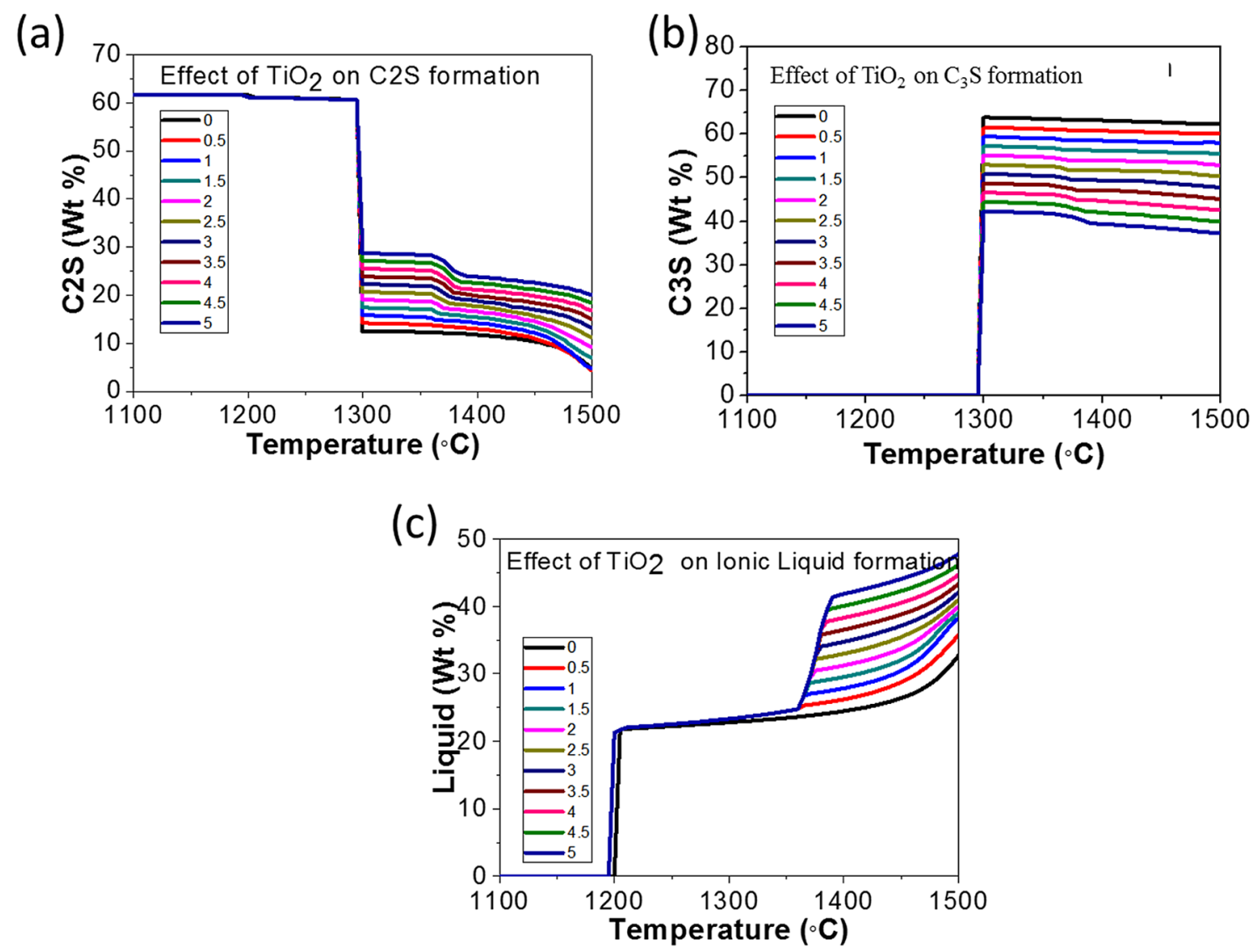

Fig. 11 Effect of $\mathrm{TiO}_{2}$ on phase formation in C-A-S-F-M system
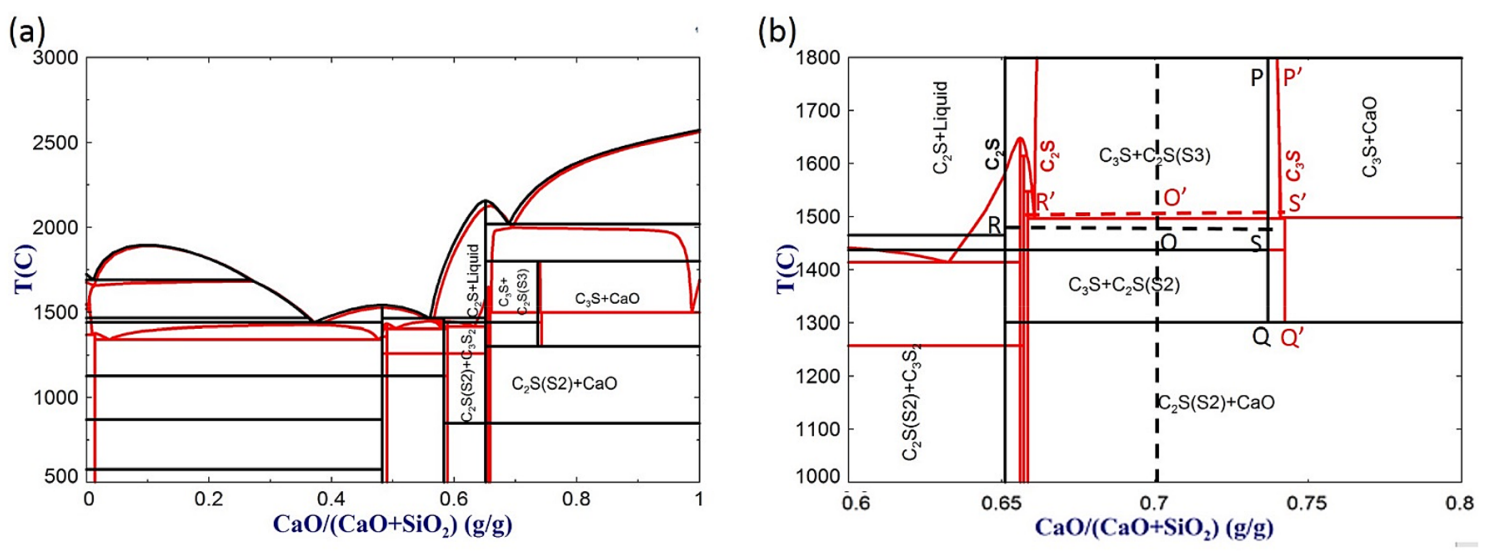

With $0 \mathrm{Wt} \% \mathrm{TiO}_{2}$

With $2 \mathrm{Wt} \% \mathrm{TiO}_{2}$

Fig. 12 a Effect of addition of $2 \mathrm{wt} \% \mathrm{TiO}_{2}$ on $\mathrm{CaO}-\mathrm{SiO}_{2}$ system and $\mathbf{b}$ magnified view of fig. a shows the effect on $\mathrm{C}_{3} \mathrm{~S}$ and $\mathrm{C}_{2} \mathrm{~S}$ formation

Figure 14 shows the effect of addition of different mineralizers on ionic liquid formation of $\mathrm{C}-\mathrm{A}-\mathrm{S}-\mathrm{F}-\mathrm{M}$ system. It shows that the weight percent of ionic liquid increases with increasing doses of different mineralizer. $\mathrm{AlF}_{3}$ has the maximum effect on increasing ionic liquid compared to other mineralizers whereas, $\mathrm{ZnO}$ and $\mathrm{CaSO}_{4}$ have very marginal effect in increasing ionic liquid. Up to 0.5 wt\%, both $\mathrm{MgSiF}_{6}$ and $\mathrm{Na}_{2} \mathrm{SiF}_{6}$ have similar effect. But, $\mathrm{MgSiF}_{6}$ is more effective compared to $\mathrm{Na}_{2} \mathrm{SiF}_{6}$ when their proportion is more than $5 \mathrm{wt} \%$. 
(a)

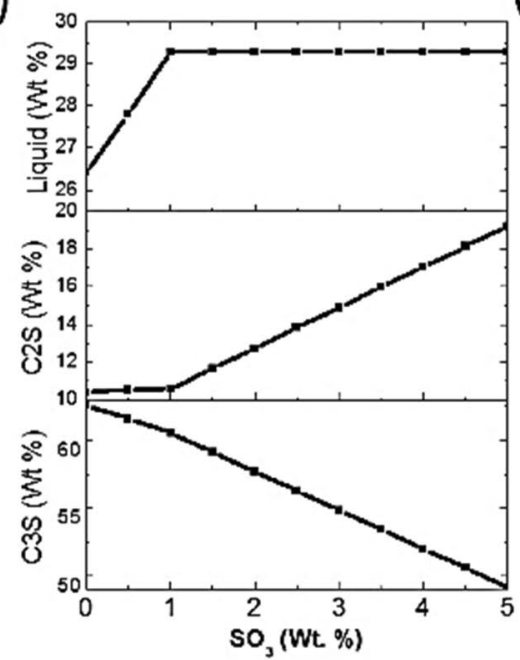

(d)

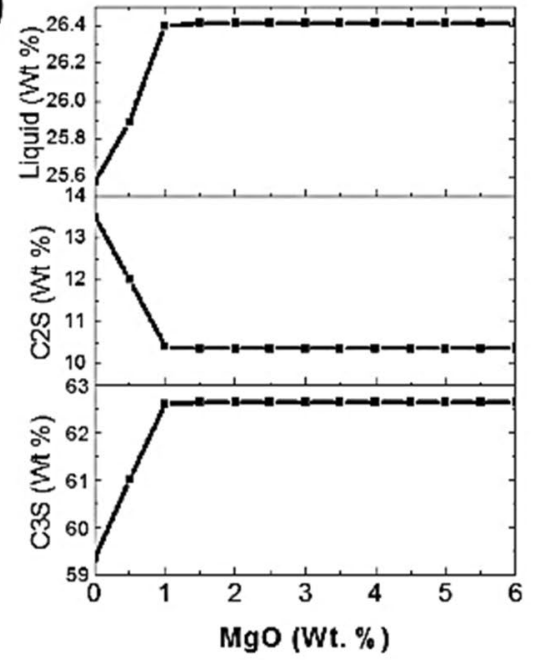

(b)

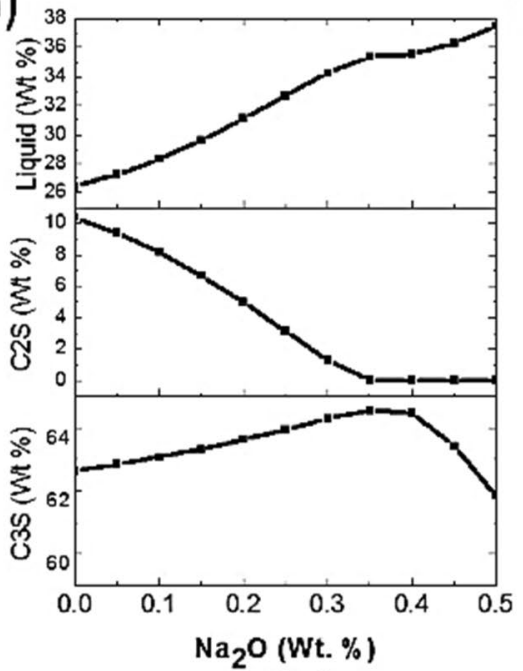

(e) (c)

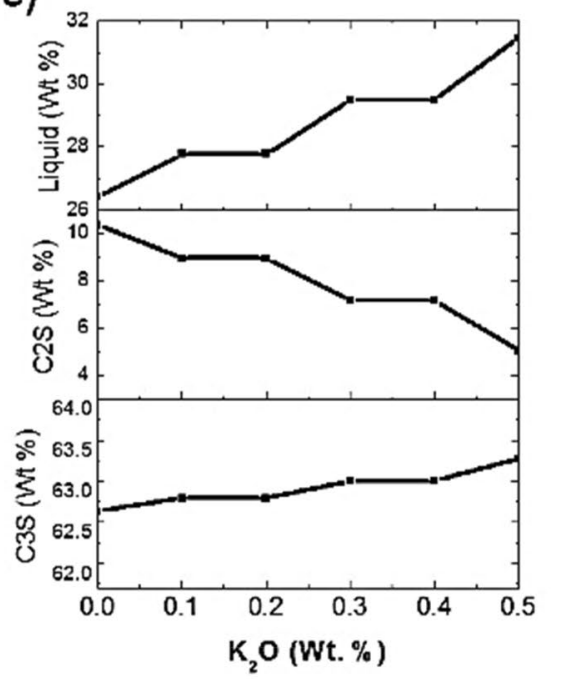

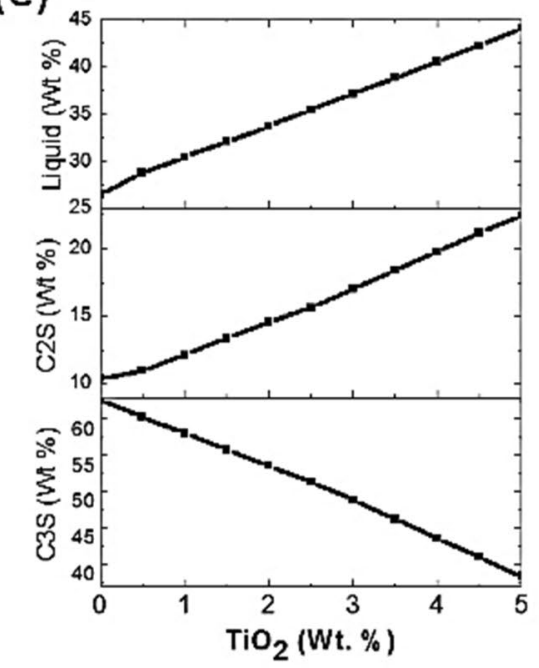

Fig. 13 Effect plot of $\mathbf{a ~ S O}{ }_{3}, \mathbf{b ~ N a} \mathrm{Na}_{2} \mathrm{O}, \mathrm{c} \mathrm{K}_{2} \mathrm{O}, \mathbf{d} \mathrm{MgO}$ and $\mathbf{e} \mathrm{TiO}_{2}$ on phase formation of $\mathrm{C}-\mathrm{A}-\mathrm{S}-\mathrm{F}-\mathrm{M}$ system at $1450^{\circ} \mathrm{C}$

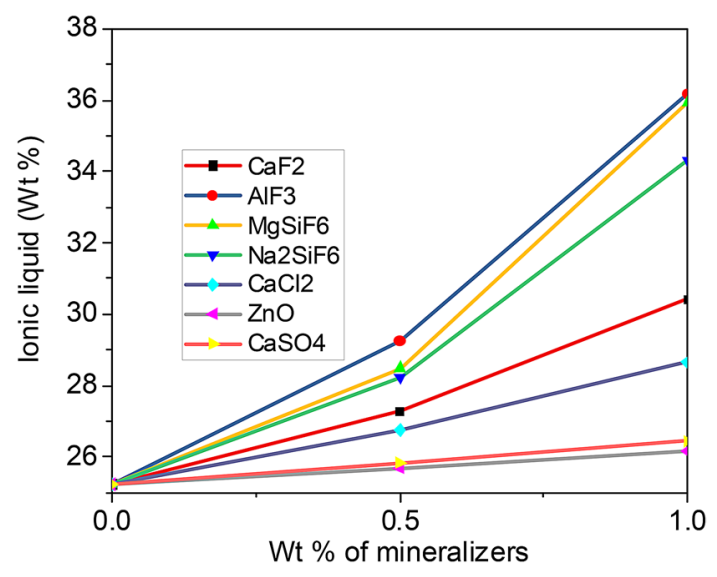

Fig. 14 Effect of mineralizer on the formation of liquid phase at $1400^{\circ} \mathrm{C}$
After $\mathrm{Na}_{2} \mathrm{SiF}_{6}, \mathrm{CaF}_{2}$ is more effective in increasing ionic liquid compared to $\mathrm{CaCl}_{2}$. The order of the mineralizers based on the ability of assisting ionic liquid formation is: $\mathrm{AlF}_{3}>\mathrm{MgSiF}_{6}>\mathrm{Na}_{2} \mathrm{SiF}_{6}>\mathrm{CaF}_{2}>\mathrm{CaCl}_{2}>\mathrm{CaSO}_{4}>\mathrm{ZnO}$. This plot is very useful to compare the effectiveness of different mineralizers and to decide the required dosages of a mineralizer.

Figure $15 a, b$ depicts the effect of increasing mineralizers on the formation of $\mathrm{C}_{3} \mathrm{~S}$ and $\mathrm{C}_{2} \mathrm{~S}$. Thus far, it has been observed that mineralizers also have serious impact on $\mathrm{C}_{3} \mathrm{~S}$ and $\mathrm{C}_{2} \mathrm{~S}$ formation while increasing ionic liquid. $\mathrm{AlF}_{3}$, $\mathrm{MgSiF}_{6}$ and $\mathrm{Na}_{2} \mathrm{SiF}_{6}$ have prominent effect in decreasing $\mathrm{C}_{3} \mathrm{~S}$ whereas, $\mathrm{CaF}_{2}$ and $\mathrm{CaCl}_{2}$ have moderate effect as shown in Fig. 15a. Although, in case of $\mathrm{ZnO}$ and $\mathrm{CaSO}_{4}$, increases $\mathrm{C}_{3} \mathrm{~S}$ marginally. Figure $15 \mathrm{~b}$ displays, $\mathrm{AlF}_{3}, \mathrm{MgSiF}_{6}$ and $\mathrm{Na}_{2} \mathrm{SiF}_{6}$ have significant effect in increasing $\mathrm{C}_{2} \mathrm{~S}$. Addition of $\mathrm{AlF}_{3}, \mathrm{MgSiF}_{6}$ and $\mathrm{Na}_{2} \mathrm{SiF}_{6}$ by $0.5 \mathrm{wt} \%$ can be 


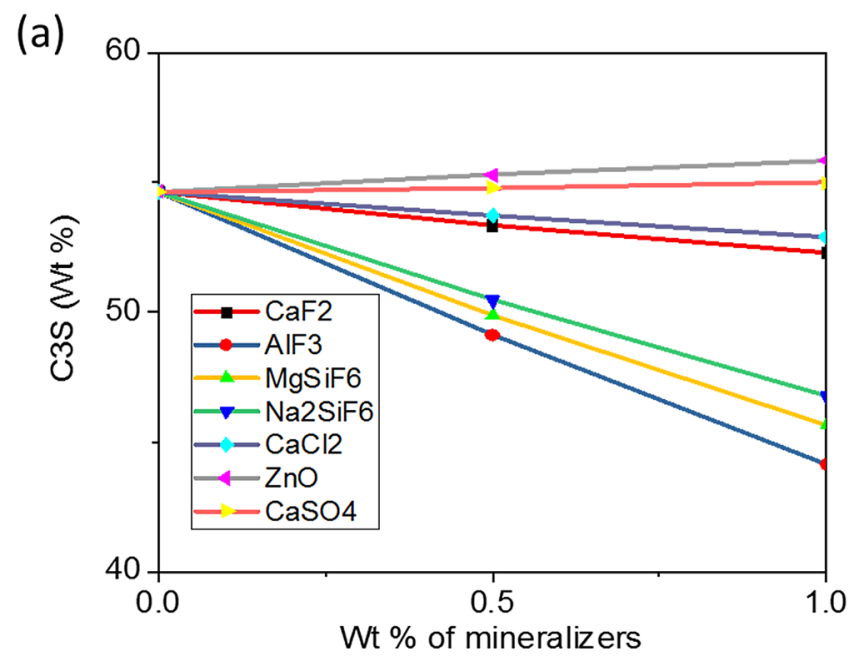

Fig. 15 Effect of mineralizers on formation of $\mathbf{a} \mathrm{C}_{3} \mathrm{~S}$ and $\mathbf{b} \mathrm{C}_{2} \mathrm{~S}$ at $1400^{\circ} \mathrm{C}$ effective in increasing $\mathrm{C}_{2} \mathrm{~S}$ by $2 \mathrm{wt} \%$. Above $0.5 \mathrm{wt} \%$, it reduces $\mathrm{C}_{2} \mathrm{~S}$ in the system. $\mathrm{CaSO}_{4}$ and $\mathrm{CaCl}_{2}$ have negligible effect in decreasing $\mathrm{C}_{2} \mathrm{~S}$. $\mathrm{CaF}_{2}$ has comparatively higher effect on decreasing $\mathrm{C}_{2} \mathrm{~S}$ when it is more than $0.5 \mathrm{wt} \%$.

From the above results, it can be observed that, fluorides are more effective in increasing the ionic liquid phase, decreasing $\mathrm{C}_{3} \mathrm{~S}$ and increasing $\mathrm{C}_{2} \mathrm{~S}$ compared to other types of mineralizers. If only fluorides are considered, the order of the effectiveness of fluorides also depends on the total fluorine content in the system. The wt\% fluorine in $\mathrm{MgSiF}_{6}$ and $\mathrm{AlF}_{3}$ are maximum, $68.51 \mathrm{wt} \%$ and 67.85 wt\% respectively. But, added advantage of 'Al' which is present in $\mathrm{AlF}_{3}$, makes it marginally more effective compared to $\mathrm{MgSiF}_{6} \mathrm{Na}_{2} \mathrm{SiF}_{6}$ is also very effective mineralizer containing $60.61 \mathrm{wt} \%$ of fluorine. Finally, $\mathrm{CaF}_{2}$ is the least influential fluoride mineralizer among them having very low fluoride content (48.66 wt\%). With increasing ionic liquid, the solubility of $\mathrm{Ca}^{2+}$ in the ionic liquid also increases. So, the available free calcium decreases in the system and reacts with $C_{2} S$ to form $C_{3} S$. As a result, the $C_{3} S$ decreases with increasing ionic liquid and $\mathrm{C}_{2} S$ increases. The variation of $\mathrm{C}_{3} \mathrm{~S}$ and $\mathrm{C}_{2} \mathrm{~S}$ is related to the ionic liquid formation.

Figure 16 shows the effect of all the mineralizers on the reduction of clinkerization temperature. Here, clinkerization temperature is assumed to be the temperature at which $25 \mathrm{wt} \%$ ionic liquid forms. It shows, by the addition of $0.5 \mathrm{wt} \%$ and $1 \mathrm{wt} \%$ of $\mathrm{AlF}_{3}$, clinkerization temperature can be reduced by $\sim 150^{\circ} \mathrm{C}$ and $\sim 250^{\circ} \mathrm{C}$ respectively. Both $\mathrm{Na}_{2} \mathrm{SiF}_{6}$ and $\mathrm{MgSiF}_{6}$, can reduce clinkerization temperature by $\sim 100^{\circ} \mathrm{C}$ and $\sim 200^{\circ} \mathrm{C}$ by the addition of $0.5 \mathrm{wt} \%$ and $1 \mathrm{wt} \%$ respectively. $\mathrm{CaF}_{2}$ has comparatively higher effect in reducing clinkerization temperature compared to $\mathrm{CaCl}_{2}$ whereas, $\mathrm{CaSO}_{4}$ and $\mathrm{ZnO}$ has the least effect. So, fluorides are the most effective mineralizer, followed by
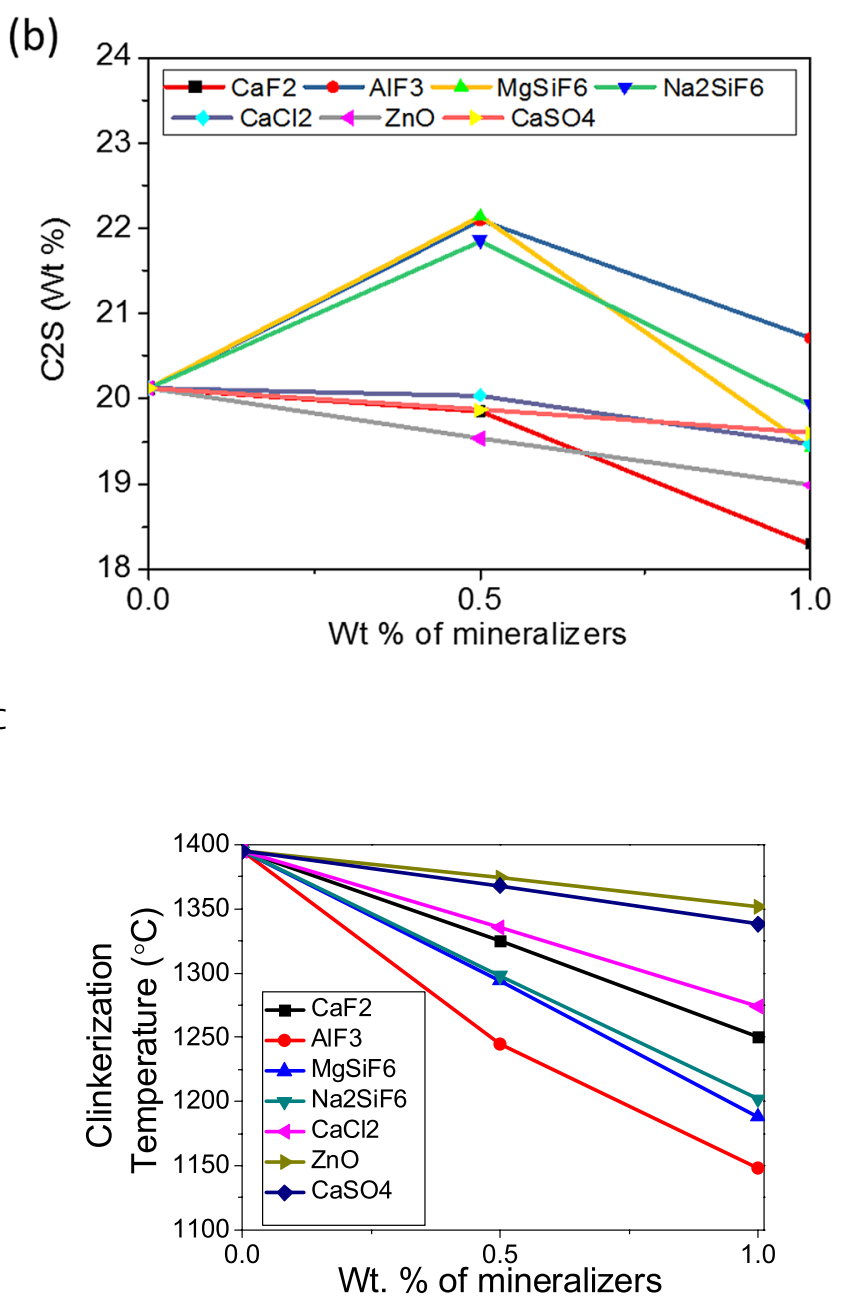

Fig. 16 Effect of mineralizer on clinkerization temperature

chlorides and sulphates to reduce clinkerization temperature. To compare the effects of different mineralizers, linear regression model $(Y=A+B X$, where $A$ and $B$ are the constant) was developed. Table 7 summarizes the result of the regression analysis. The coefficient of $X$ or the slope of the curve, represents the effectiveness of the mineralizer. $\mathrm{AlF}_{3}$ is the most effective mineralizer as it has lowest value $(-247)$ of the coefficient and $\mathrm{ZnO}$ is the least effective mineralizer having highest value of coefficient of $X$ $(-43)$. The clinkerization temperature can be calculated easily by using these equations within the range of 0 to 1 wt $\%$.

Although $\mathrm{AlF}_{3}$ is one of the most effective mineralizer however, it is very expensive. But, it is possible to combine a proportion of currently practiced mineralizer (such as $\left(\mathrm{CaF}_{2}\right.$ ) with $\mathrm{AlF}_{3}$ to enhance the overall performance of the mineralizer. Figure 17 shows the result of combined effect of different mineralizers in reducing clinkerization temperature. It shows that both $\mathrm{CaF}_{2}$ and $\mathrm{CaCl}_{2}$ is highly 
Table 7 Effect of mineralizer on clinkerization temperature

\begin{tabular}{llll}
\hline Mineralizer $(\mathrm{Y})$ & \multicolumn{2}{l}{$\begin{array}{l}\text { Regression equation } \\
(\mathrm{Y}=\mathrm{A}+\mathrm{B} . \mathrm{X})\end{array}$} & $\mathrm{R}^{2}$-adj \\
\cline { 2 - 4 } & $\mathrm{A}$ & $\mathrm{B}$ & \\
\hline $\mathrm{CaF}_{2}$ & 1396 & -145 & 100 \\
$\mathrm{AlF}_{3}$ & 1386.2 & -247 & 98.5 \\
$\mathrm{MgSiF}_{6}$ & 1396 & -207 & 100 \\
$\mathrm{Na}_{2} \mathrm{SiF}_{6}$ & 1395 & -193 & 100 \\
$\mathrm{CaCl}_{2}$ & 1395 & -121 & 100 \\
$\mathrm{ZnO}$ & 1395 & -43 & 100 \\
$\mathrm{CaSO}_{4}$ & 1395 & -57 & 99 \\
\hline
\end{tabular}

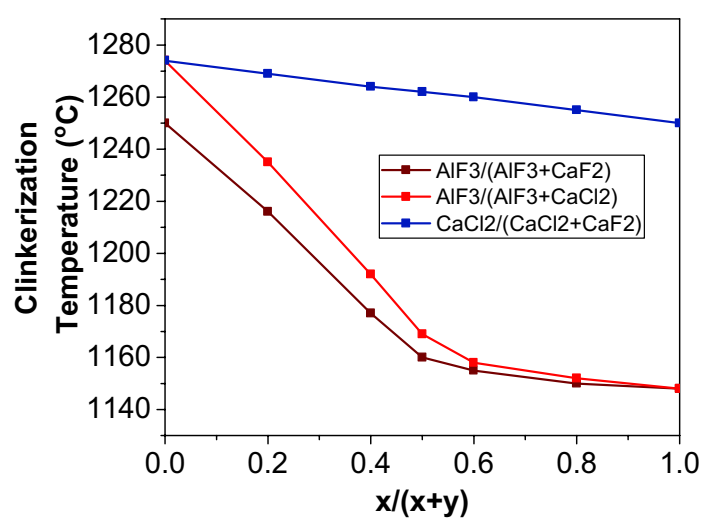

Fig. 17 Combined effect of mineralizers on reduction of clinkerization temperature

effective in reducing clinkerization temperature with addition of $\mathrm{AlF}_{3}$ up to $0.6 \%$. Above $0.6 \%, \mathrm{AlF}_{3}$ is not much effective in reducing clinkerization temperature. $\mathrm{But}_{1} \mathrm{CaF}_{2} \mathrm{can}$ reduce the clinkerization temperature linearly by replacing $\mathrm{CaCl}_{2}$ up to $1 \mathrm{wt} \%$ although the effect is quite minimal compared to $\mathrm{AlF}_{3}$ as shown in Fig. 17.

\section{Summary and conclusions}

The influence of important minor oxides and mineralizers on Portland cement phase formation has been investigated in detail through current CALPHAD study. It was also found that many of our findings through CALPHAD simulation were in line with the observations reported by many researchers as mentioned earlier. Through this study, the usefulness of available CALPHAD software i.e., FactSage to analyze the cement clinker has been demonstrated as it has the spin off benefit of considering minor constituents and process conditions $(T, P)$ in the calculation to predict the clinker phases more accurately.

This study demonstrates how different minor oxides and mineralizers play vital role in influencing the cement phase formation. Increasing $\mathrm{SO}_{3}$ and $\mathrm{TiO}_{2}, \mathrm{C}_{2} \mathrm{~S}$ increases and $\mathrm{C}_{3} \mathrm{~S}$ decreases in the clinker. On the other hand, presence of alkalies $\left(\mathrm{Na}_{2} \mathrm{O}\right.$ and $\left.\mathrm{K}_{2} \mathrm{O}\right)$ increase $\mathrm{C}_{3} \mathrm{~S}$ and decrease $\mathrm{C}_{2} \mathrm{~S}$. Although all the minor oxides assist formation of ionic liquid. Most of the minor oxides also critically assist in increasing the burnability of raw mix and thereby benefits in fuel saving. So, the presence of alkalis $\left(\mathrm{Na}_{2} \mathrm{O}\right.$ and $\left.\mathrm{K}_{2} \mathrm{O}\right)$ are desirable up to a certain limit in order to help clinkerization process as they assist in ionic liquid formation. $\mathrm{MgO}$ is one of the most common oxide present in clinker as up to $2 \mathrm{wt} \%$, it helps in clinkerization process by decreasing ionic liquid formation temperature and by increasing $\mathrm{C}_{3} \mathrm{~S}$ content [2]. Excess $\mathrm{MgO}$ in the clinker remains unreacted and causes expansion problem during hydration. Hence, the use of $\mathrm{MgO}$ is restricted to a maximum limit of $6 \mathrm{wt} \%$ to suppress the detrimental effect [5].

The effect of selected mineralizers has also been studied using CALPHAD. Fluoride mineralizers are found to be superior in terms of reducing clinkerization temperature. Among all the fluorides, $\mathrm{AlF}_{3}$ is the most effective mineralizer compared to other fluorides. The order of the effectiveness in reducing clinkerization temperature of the mineralizers are: $\mathrm{AlF}_{3}>\mathrm{MgSiF}_{6}>\mathrm{Na}_{2} \mathrm{SiF}_{6}>\mathrm{CaF}_{2}>\mathrm{CaCl}_{2}>\mathrm{CaSO}_{4}>\mathrm{ZnO}$. It was also observed, most of the mineralizers reduce $\mathrm{C}_{3} \mathrm{~S}$ and increase $\mathrm{C}_{2} \mathrm{~S}$ while increasing ionic liquid. So, deciding the dosage of mineralizer is very critical as it has a direct impact on the final properties of cement.

This study also establishes that CALPHAD based phase equilibria calculation approach is a highly effective tool and valuable addition in the understanding and analysis of minor oxides and mineralizers in $\mathrm{C}-\mathrm{A}-\mathrm{S}-\mathrm{F}-\mathrm{M}$ system.

Acknowledgement The authors are sincerely grateful to the analytical team of ABSTCPL for helping in XRD and XRF experiments.

\section{Compliance with ethical standards}

Conflict of interest No potential conflict of interest was reported by the authors.

\section{References:}

1. Hewlett PC (2003) Lea's chemistry of cement and concrete. Butterworth-Heinemann, Oxford

2. Ghosh SN (1983) Advances in cement technology. Elsevier, Amsterdam

3. Bapat JD (2012) Mineral admixtures in cement and concrete. CRC Press, Boca Raton

4. De Schepper M, Van den Heede P, Arvaniti EC, et al (2017) Sulfates in completely recyclable concrete and the effect of $\mathrm{CaSO}_{4}$ on the clinker mineralogy. In: Construction and building materials, pp 300-306 
5. Herfort D, Moir GK, Johansen V et al (2010) The chemistry of Portland cement clinker. Reinhold Publishing Corporation, New York

6. Tazuddin A, Aiyer HN, Chatterjee A (2018) Phase equilibria studies of $\mathrm{CaO}-\mathrm{SiO}_{2}-\mathrm{Al}_{2} \mathrm{O}_{3}-\mathrm{Fe}_{2} \mathrm{O}_{3}-\mathrm{MgO}$ system using CALPHAD. Calphad Comput Coupl Phase Diagrams Thermochem 60:116-125. https://doi.org/10.1016/j.calphad.2017.12.003

7. Barros AM, Espinosa DCR, Tenório JAS (2004) Effect of $\mathrm{Cr} 2 \mathrm{O} 3$ and $\mathrm{NiO}$ additions on the phase transformations at high temperature in Portland cement. Cem Concr Res 34:1795-1801. https:// doi.org/10.1016/j.cemconres.2004.01.016

8. De Noirfontaine MN, Tusseau-Nenez S, Girod-Labianca C, Pontikis V (2012) CALPHAD formalism for Portland clinker: thermodynamic models and databases. J Mater Sci 47:1471-1479. https ://doi.org/10.1007/s10853-011-5932-7

9. Brown WE, Chow LC (2004) Combinations of sparingly soluble calcium phosphates in slurries and pastes as mineralizers and cements

10. Chatterjee TK (1983) Burnability and clinkerization of cement raw mixes. Adv Cem Technol. https://doi.org/10.1016/b978-008-028670-9.50009-0

11. Kacimi L, Simon-Masseron A, Ghomari A, Derriche Z (2006) Influence of $\mathrm{NaF}, \mathrm{KF}$ and $\mathrm{CaF} 2$ addition on the clinker burning temperature and its properties. Comptes Rendus Chim 9:154-163. https://doi.org/10.1016/j.crci.2005.10.001

12. Mehrotra S, Tehri S (1993) Effectiveness of different mineralizers in cement manufacture. Indian J Technol 31:535-538

13. Altun IA (1999) Effect of $\mathrm{CaF}_{2}$ and $\mathrm{MgO}$ on sintering of cement clinker. Cem Concr Res 29:1847-1850. https://doi.org/10.1016/ S0008-8846(99)00151-9

14. Lukas HL, Fries SG, Sundman B (2007) Computational thermodynamics: the Calphad method. Cambridge University Press, Cambridge

15. Tazuddin A, Gurao NP, Biswas K (2017) In the quest of single phase multi-component multiprincipal high entropy alloys. J Alloys Compd 697:434-442. https://doi.org/10.1016/j.jallc om.2016.11.383

16. Fabrichnaya OB, Saxena SK, Richet P, Westrum EF (2004) Calculation of phase diagrams. Curr Opin Solid State Mater Sci 1:137-171. https://doi.org/10.1007/978-3-662-10504-7_5

17. Bale CW, Bélisle E, Chartrand P et al (2016) FactSage thermochemical software and databases, 2010-2016. Calphad Comput
Coupl Phase Diagrams Thermochem 54:35-53. https://doi. org/10.1016/j.calphad.2016.05.002

18. Andersson JO, Helander T, Höglund L et al (2002) Thermo-Calc \& DICTRA, computational tools for materials science. Calphad Comput Coupl Phase Diagrams Thermochem 26:273-312. https ://doi.org/10.1016/S0364-5916(02)00037-8

19. Davies RH, Dinsdale AT, Gisby JA et al (2002) MTDATA - Thermodynamic and phase equilibrium software from the national physical laboratory. Calphad Comput Coupl Phase Diagrams Thermochem 26:229-271. https://doi.org/10.1016/S0364 $-5916(02) 00036-6$

20. Coelho AA (2005) Topas: general profile and structure analysis software for powder diffraction data. Bruker AXS

21. Taylor HFW (1997) Cement chemistry. Cem Chem. https://doi. org/10.1680/cc.25929

22. Deschenes LA (2000) Origin 6.0: Scientific Data Analysis and Graphing Software Origin Lab Corporation (formerly Microcal Software, Inc.). Web site: www.originlab.com. Commercial price: \$595. Academic price: \$446. J Am Chem Soc 122:9567-9568

23. Gutt W, Smith MA (1968) Studies of the role of calcium sulphate in the manufacture of Portland cement clinker

24. Horkoss S, Lteif R, Rizk T (2010) Calculation of the percentage in high sulfur clinker. Int J Anal Chem 2010:1-5. https://doi. org/10.1155/2010/102146

25. Li X, Xu W, Wang S et al (2014) Effect of $\mathrm{SO}_{3}$ and $\mathrm{MgO}$ on Portland cement clinker: formation of clinker phases and alite polymorphism. Constr Build Mater 58:182-192. https://doi.org/10.1016/j. conbuildmat.2014.02.029

26. Gotti E, Marchi M, Costa U (2007) Influence of alkalis and sulphates on the mineralogical composition of clinker. In: 12th International Congress on the Chemistry of Cement

27. Pacheco-Torgal F, Jalali S, Labrincha J, John VM (2013) Eco-efficient concrete. Elsevier, Amsterdam

28. Ma X, Chen H, Wang P (2009) Effect of $\mathrm{TiO}_{2}$ on the formation of clinker with high C 3S. J Wuhan Univ Technol Mater Sci Ed 24:830-833. https://doi.org/10.1007/s11595-009-5830-x

Publisher's Note Springer Nature remains neutral with regard to jurisdictional claims in published maps and institutional affiliations. 